Marquette University

e-Publications@Marquette

Biomedical Sciences Faculty Research and

Publications

Biomedical Sciences, Department of

9-21-2011

\title{
Glutamatergic Plasticity in Medial Prefrontal Cortex and Ventral Tegmental Area Following Extended-Access Cocaine Self-Administration
}

Behnam Ghasemzadeh

Marquette University, behnam.ghasemzadeh@marquette.edu

Preethi Vasudevan

Marquette University

Chad Giles

Marquette University

Anthony Purgianto

Marquette University

Chad Seubert

Marquette University

See next page for additional authors

Accepted version. Brain Research, Vol. 1413 (September 21, 2011): 60-71. DOI. (C) 2011 Elsevier. Used with permission. 
Authors

Behnam Ghasemzadeh, Preethi Vasudevan, Chad Giles, Anthony Purgianto, Chad Seubert, and John R. Mantsch 


\title{
Glutamatergic Plasticity in Medial Prefrontal Cortex and Ventral Tegmental Area Following Extended- Access Cocaine Self-Administration
}

\author{
M. Behnam Ghasemzadeh \\ Department of Biomedical Sciences, Integrative Neuroscience \\ Research Center, Marquette University \\ Milwaukee, WI \\ Preethi Vasudevan \\ Department of Biomedical Sciences, Integrative Neuroscience \\ Research Center, Marquette University \\ Milwaukee, WI \\ Chad Giles \\ Department of Biomedical Sciences, Integrative Neuroscience \\ Research Center, Marquette University \\ Milwaukee, WI \\ Anthony Purgianto \\ Department of Biomedical Sciences, Integrative Neuroscience \\ Research Center, Marquette University \\ Milwaukee, WI
}




\author{
Chad Seubert \\ Department of Biomedical Sciences, Integrative Neuroscience \\ Research Center, Marquette University \\ Milwaukee, WI \\ John R. Mantsch \\ Department of Biomedical Sciences, Integrative Neuroscience \\ Research Center, Marquette University \\ Milwaukee, WI
}

\begin{abstract}
Glutamate signaling in prefrontal cortex and ventral tegmental area plays an important role in the molecular and behavioral plasticity associated with addiction to drugs of abuse. The current study investigated the expression and postsynaptic density redistribution of glutamate receptors and synaptic scaffolding proteins in dorsomedial and ventromedial prefrontal cortex and ventral tegmental area after cocaine self-administration. After 14 days of extended-access (6hr/day) cocaine self-administration, rats were exposed to one of three withdrawal regimen for 10 days. Animals either stayed in home cages (Home), returned to self-administration boxes with the levers withdrawn (Box), or underwent extinction training (Extinction).

Extinction training was associated with significant glutamatergic plasticity. In dorsomedial prefrontal cortex of the Extinction group, there was an increase in postsynaptic density GluR1, PSD95, and actin proteins; while postsynaptic content of mGluR5 receptor protein decreased and there was no change in NMDAR1, Homer1b/c, or PICK1 proteins. These changes were not observed in ventromedial prefrontal cortex or ventral tegmental area. In ventral tegmental area, Extinction training reversed the decreased postsynaptic density NMDAR1 protein in the Home and Box withdrawal groups. These data suggest that extinction of drug seeking is associated with selective glutamatergic plasticity in prefrontal cortex and ventral tegmental area that include modulation of receptor trafficking to postsynaptic density.
\end{abstract}

Keywords: AMPA, NMDA, mGluR5, Homer, PICK1, Actin, addiction, scaffolding proteins, synaptic plasticity, postsynaptic density, abstinence, extinction

\title{
1. Introduction
}

Addiction is characterized as transition from episodic drug use to compulsive use and loss of control over drug intake (Leshner AI, 1997;

[Citation: Journal/Monograph Title, Vol. XX, No. X (yyyy): pg. XX-XX. DOI. This article is @ [Publisher's Name] and permission has been granted for this version to appear in e-Publications@Marquette. [Publisher] does not grant permission for this article to be further copied/distributed or hosted elsewhere without the express permission from [Publisher].] 
Kalivas and Volkow, 2005; O'Brien and McLellan, 1996). A major obstacle in treatment of addiction is the unpredictable relapse to drug use during abstinence, often mediated by drug-associated cues (O'Brien, 1997; Kreek and Koob, 1998). Emerging data suggest that long-lasting plasticity in glutamatergic signaling in the brain play an important role in drug craving and relapse (Ghasemzadeh et al., 2009a,b; Anderson et al., 2008; Conrad et al., 2008; Self et al., 2004). These studies have identified a brain circuit encompassing a number of loci including prefrontal cortex, nucleus accumbens and ventral tegmental area as pivotal anatomical substrates mediating addiction behaviors (Thomas et al., 2008; Kalivas and McFarland, 2003; Kalivas, 2009; Ghasemzadeh et al., 2009a,b).

Prefrontal cortex, a component of the motive circuit of the brain, has been implicated in the behavioral and molecular changes after repeated exposure to cocaine (Steketee, 2003; McFarland and Kalivas, 2001, McFarland et al., 2004; Kalivas, 2009). The pyramidal projection neurons of the prefrontal cortex innervate subcortical regions, such as nucleus accumbens, amygdala and ventral tegmental area, and provide excitatory glutamatergic neurotransmission (Brinley-Reed et al., 1995; Sesack et al., 1989, Sesack and Pickel, 1992; Groenewegen et al., 1990). The medial prefrontal cortex in the rat is a heterogeneous structure that can be subdivided into dorsal and ventral compartments based on the functional and anatomical distinctions (Berendse et al., 1992; Heidbreder and Groenewegen, 2003). The dorsomedial prefrontal cortex (dmPFC) consists of the cingulate cortex area 1 and the dorsal portion of the prelimbic cortex and preferentially innervates the dorsal striatum and nucleus accumbens core regions (Sesack et al., 1989; Groenewegen et al., 1990; Berendse et al., 1992). The ventromedial prefrontal cortex (VmPFC) consists of the ventral portion of the prelimbic and the infralimbic cortex and preferentially innervates the nucleus accumbens shell (Sesack et al., 1989; Hurley et al., 1991; Gorelova and Yang, 1997). The mPFC is innervated by the dopaminergic afferents from the ventral tegmental area (VTA) with the highest innervation received in the infralimbic and prelimbic regions (Conde et al., 1995; Lindval et al., 1978; Thierry et al., 1973). In turn, the medial prefrontal cortex innervates the ventral tegmental area with prelimbic cortex exhibiting a larger innervation than cingulate or infralimbic regions (Beckstead, 1979; Sesack et al., 1989; Hurley et al., 1991; Sesack and Pickel, 1992). permission has been granted for this version to appear in e-Publications@Marquette. [Publisher] does not grant permission for this article to be further copied/distributed or hosted elsewhere without the express permission from [Publisher].] 
Several studies have suggested a critical role for rat medial prefrontal cortex in drug seeking and relapse. Furthermore, the dorsal and ventral compartments of mPFC exert distinct regulation on drugseeking behaviors suggesting a functional dichotomy between mPFC compartments. Injection of cocaine into prefrontal cortex is reinforcing and reinstates cocaine-seeking behavior (Guzman et al., 2009; Park et al., 2002). BDNF infusion into PFC reduced cocaine seeking (Berglind et al., 2007). Inhibition of dmPFC, but not vmPFC, by GABA receptor agonists prevented cocaine and footshock-mediated reinstatement of drug seeking (McFarland and Kalivas, 2001; McFarland et al., 2004). Inactivation of prelimbic cortex or dmPFC attenuates drug-taking and drug-seeking behaviors (Capriles et al., 2003; McLaughlin and See, 2003; Di Pietro et al., 2006). Cocaine self-administration increased dendritic branching and spine density of prefrontal cortex pyramidal neurons (Robinson et al., 2001). Lastly, chronic exposure to cocaine is associated with prefrontal cortex-dependent cognitive dysfunction in preclinical models (Briand et al., 2008) as well as human addicts (Bolla et al., 2003; Cunha et al., 2010).

Similar to other membrane bound receptors, postsynaptic glutamate receptor signaling is partly regulated by the presence of functional receptor on the cell membrane and receptor-mediated intracellular signaling (Malinow and Malenka, 2002; Kennedy, 2000; Kennedy and Ehlers, 2006; Derkach et al., 2007). Therefore, glutamate receptor gene activation, protein synthesis, membrane trafficking, synaptic localization, and intracellular signaling are important candidates as possible mechanisms for cocaine-mediated plasticity. In support of these observations, we have recently shown that repeated non-contingent exposure to cocaine or cocaine selfadministration is associated with an extensive trafficking and redistribution of glutamate receptors in the nucleus accumbens and prefrontal cortex (Ghasemzadeh et al., 2009a,b,c,d). Furthermore, neuroimaging of addicts suggest abnormalities in frontal cortical neuronal activity during withdrawal as well as craving and drug use (Goldstein and Volkow, 2002; Kalivas and Volkow, 2005). Two recent report, using primary prefrontal cortex neuronal cultures, have indicated that brief D1 dopamine receptor stimulation leads to augmented trafficking and membrane expression of AMPA and NMDA receptor subunits on the pyramidal neurons (Sun et al., 2005b; Gao and Wolf, 2008). These studies suggest that plasticity in the glutamate

[Citation: Journal/Monograph Title, Vol. XX, No. X (yyyy): pg. XX-XX. DOI. This article is @ [Publisher's Name] and permission has been granted for this version to appear in e-Publications@Marquette. [Publisher] does not grant permission for this article to be further copied/distributed or hosted elsewhere without the express permission from [Publisher].] 
receptors in the prefrontal cortex may contribute to addiction-related behaviors. However, the nature and mechanisms of the glutamate receptor neuroadaptations in the prefrontal cortex after repeated exposure to cocaine is not clear. This information is critical since it provides a framework to enhance our understanding of the role of the glutamate signaling in addiction.

In order to identify glutamatergic plasticity associated with drug seeking, the current study investigated the redistribution of the glutamate receptors in the medial prefrontal cortex and ventral tegmental area after extended-access cocaine self-administration followed by three post self-administration withdrawal regimens differentiated according to the level of drug-seeking behavior that they produced. We have previously found that, depending on the post selfadministration withdrawal regimen applied, cocaine seeking varies significantly, with high levels of cocaine seeking observed when rats remain in their home cages (Abstinence), intermediate levels observed when rats are exposed to the self-administration boxes in the absence of the previously reinforced drug lever (Box), and very low levels observed when rats undergo extinction training (Extinction) (Ghasemzadeh et al., 2009a; 2009b). Additionally, the examination of glutamatergic plasticity that is associated these conditions may provide insight into alterations in glutamatergic neurotransmission in the medial prefrontal cortex and ventral tegmental area that may contribute to the extinction of drug-seeking behavior.

The trafficking of glutamate receptor proteins was monitored by utilizing a biochemical subcellular fractionation procedure, which isolates the cellular synaptosomal membrane fraction containing the postsynaptic density (Xiao et al., 1998; Lin et al., 1998; Wyszynski et al., 1998; Dunah and Standaert, 2001; Toda et al., 2003). This study is the first to report on redistribution of the three subtypes of the glutamate receptors in synaptosomal membrane fraction associated with the postsynaptic density after withdrawal from cocaine selfadministration in prefrontal cortex and ventral tegmental area. Furthermore, our data demonstrate that receptor redistribution is both withdrawal- and region-dependent suggesting a unique role for glutamate receptor signaling in drug seeking after abstinence and extinction of drug seeking. permission has been granted for this version to appear in e-Publications@Marquette. [Publisher] does not grant permission for this article to be further copied/distributed or hosted elsewhere without the express permission from [Publisher].] 
NOT THE PUBLISHED VERSION; this is the author's final, peer-reviewed manuscript. The published version may be accessed by following the link in the citation at the bottom of the page.

\section{Results}

The experiments in this study investigated the expression and postsynaptic density distribution of the glutamate receptor and their scaffolding proteins following withdrawal from extended-access cocaine self-administration in dmPFC, vmPFC, and VTA in male Sprague Dawley rats. In order to identify molecular plasticity in protein redistribution associated with extinction of drug-seeking behavior or forced abstinence three withdrawal conditions were examined. Following 14 days of extended-access (LgA, $1.0 \mathrm{mg} /$ infusion/200 $\mu \mathrm{l}$, $6 \mathrm{hr} /$ day) cocaine self-administration rats were divided into three groups. One group was left in home cages without any further treatment (Home). A second group of animals was brought back daily to the self-administration boxes in the absence of levers and any discrete cocaine-associated discriminative cues (Box, 6hr/day). The third group of animals underwent daily extinction training (Extinction, $6 \mathrm{hr} /$ day). All animals were killed after 10 days of withdrawal treatment and brain regions of interest were collected. Supplementary figure $1 \mathrm{~S}$ shows the PFC and VTA areas that were collected for protein analysis.

\subsection{Drug seeking depends on the withdrawal conditions}

As reported previously (Ghasemzadeh, et al., 2009a), there were no significant differences in saline or cocaine self-administration between animals assigned to any one of the three withdrawal regimens (Table 1 , Supplementary figure $2 \mathrm{~S}$ ). After withdrawal, a $6 \mathrm{hr}$ extinction session was used to measure drug seeking. During extinction session, the experimental conditions were identical to cocaine self-administration sessions and responding to the cocaine lever was recorded but cocaine was replaced by saline. There was a significant effect of withdrawal condition on subsequent drug seeking (Home, $48.8 \pm 5.2$; Box, $34.4 \pm 5.1$; Extinction, $8.8 \pm 1.6 ; F(2,22)=$ 29.916; $\mathrm{p}<0.0001)$. Fisher's PLSD post hoc analysis indicated that the drug seeking was significantly lower in Extinction rats compared to both Home and Box rats $(p<0.0001)$ and significantly lower in Box rats compared to Home rats $(p=0.026)$ (Supplementary figure $3 S$ ).

[Citation: Journal/Monograph Title, Vol. XX, No. X (yyyy): pg. XX-XX. DOI. This article is (C) [Publisher's Name] and permission has been granted for this version to appear in e-Publications@Marquette. [Publisher] does not grant permission for this article to be further copied/distributed or hosted elsewhere without the express permission from [Publisher].] 


\begin{tabular}{|c|c|c|c|}
\hline & Home & Box & Extinction \\
\hline Saline, day 1 & $6.1 \pm 1.7$ & $7.9 \pm 1.4$ & $10.4 \pm 1.8$ \\
\hline Saline, day 14 & $4.1 \pm 1.4$ & $6.2 \pm 1.0$ & $2.5 \pm 1.0$ \\
\hline Cocaine, day 1 & $38.4 \pm 5.4$ & $55.4 \pm 4.7$ & $51.9 \pm 8.0$ \\
\hline Cocaine, day 14 & $68.4 \pm 3.3$ & $64.1 \pm 7.2$ & $57.7 \pm 4.4$ \\
\hline
\end{tabular}

Six groups of animals were trained to self-administer saline or cocaine $(1.0 \mathrm{mg} / \mathrm{kg} / 200 \mu \mathrm{l}$ infusion) in 6 hour daily sessions. There were no differences between first and last days in saline or cocaine self-administration animals.

\subsection{Subcellular Fractionation of Proteins}

The biochemical fractionation employed in this study was adopted from Dunah and Standaert (2001) and has been described previously in detail (Ghasemzadeh et al., 2009a,b). A schematic is presented in Supplementary figure 1S. The efficacy of the fractionation protocol to isolate various subcellular compartments was illustrated by Dunah and Standaert (2001) and others (Lin et al., 1998; Wyszynski et al., 1998; Xiao et al., 1998; Toda et al., 2003) and was reproduced in our laboratory (Ghasemzadeh et al., 2009a,b). Synaptophysin, a presynaptic marker protein, and two intracellular organelle proteins, GM130, a Golgi membrane protein, and, Calnexin, an endoplasmic reticulum protein, were reduced in the synpatosomal membrane fraction (LP1) while being concentrated in the synaptic vesicle fraction (LS1) (Wiedenmann and Franke, 1985; Seemann et al., 2000; Rubio and Wenthold, 1999; Williams, 2006). All three intracellular proteins were separated from the synaptosomal membrane fraction (LP1) containing the postsynaptic density (PSD). In contrast, PSD95, a scaffolding protein present at the postsynaptic density (Hunt et al., 1996), was highly enriched in the synaptosomal membrane fraction (LP1 vs. $\mathrm{H}, \mathrm{LS} 1$ ). Therefore, the biochemical fractionation was able to isolate the synaptosomal membrane fraction containing the PSD from the presynaptic and cytosolic compartments. 


\subsection{Effects of withdrawal conditions on expression and postsynaptic density distribution of proteins}

All protein measurements in cocaine self-administrating animals were first compared to corresponding saline treated animals using Student's t-test. In order to assess the effect of the withdrawal treatments alone on protein levels, comparisons of saline animals were made across withdrawal conditions in dmPFC and vmPFC. One-way ANOVA did not reveal any differences between saline groups in either tissue or postsynaptic density protein levels except for mGluR5 protein as described below. Since saline groups were not different, we were able to compare cocaine-induced changes in postsynaptic density proteins across withdrawal treatments using one-way ANOVA. Subsequently, differences between individual cocaine treatment groups were examined using Fisher's PLSD post hoc test. Due to limited amount of protein available from VTA samples, we did not examine the effect of withdrawal treatments in saline treatment groups. Therefore, we could not compare protein levels in cocaine treated animals across withdrawal treatments in VTA. Representative protein bands from dmPFC, vmPFC, and VTA regions are shown in Supplementary Figures 6S-8S.

\subsubsection{GluR1 protein}

Tissue levels of GluR1 protein were not changed after any of the withdrawal treatments in dmPFC, vmPFC, or VTA (Figure 1). The postsynaptic density distribution of GluR1 protein was significantly increased in dmPFC of Extinction rats (Saline $100 \pm 2.7$, Cocaine 110.9 $\pm 3.8 ; \mathrm{t}(17)=-2.305, \mathrm{p}=0.034$ ) (Figure 1 ). However, the cocaine treated animals did not show any difference across withdrawal treatments in dmPFC PSD (one-way ANOVA, $F(2,28)=1.85, p=0.18$ ). The postsynaptic density GluR1 protein level was not changed in either vmPFC or VTA.

[Citation: Journal/Monograph Title, Vol. XX, No. X (yyyy): pg. XX-XX. DOI. This article is @ [Publisher's Name] and permission has been granted for this version to appear in e-Publications@Marquette. [Publisher] does not grant permission for this article to be further copied/distributed or hosted elsewhere without the express permission from [Publisher].] 


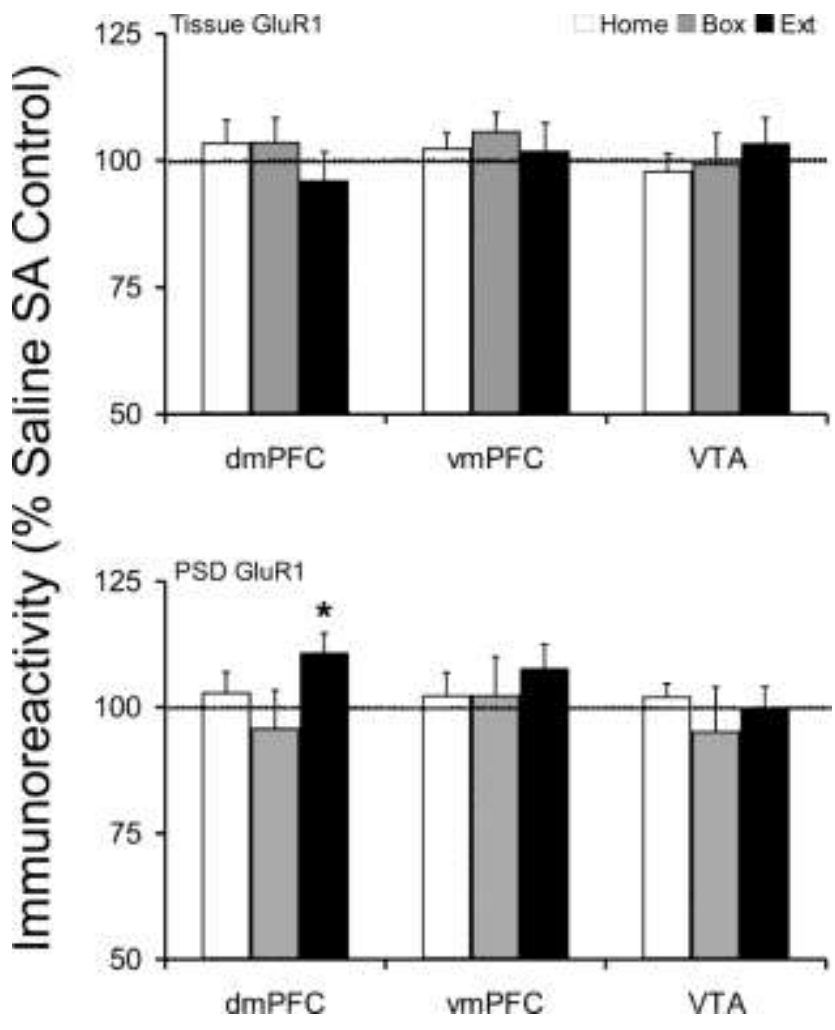

\section{Figure 1}

Tissue and postsynaptic density (synaptosomal membrane fraction) levels of GluR1 protein after cocaine self-administration and Home, Box, and Extinction treatments. Animals self-administered cocaine for 14 days (extended-access, 6h/day) and were exposed to Home, Box, or Extinction conditions during 12-14 days of post-SA period. At the tissue level, GluR1 protein was not changed in any treatment group. However, the PSD level of GluR1 protein was selectively increased in dmPFC of Extinction group. The dotted line designates percent average saline self-administration groups. $* \mathrm{p}<0.05$ compared to respective saline control.

\subsubsection{NMDAR1 protein}

The tissue or postsynaptic density level of NMDAR1 protein did not change in dmPFC or vmPFC under any withdrawal conditions. There was a near significant decrease in VTA tissue NMDAR1 protein in Extinction animals (100 \pm 5.3 , Cocaine $83.4 \pm 5.9 ; \mathrm{t}(16)=2.076$, $\mathrm{p}=0.054)$. In addition, there was a near significant decrease in VTA postsynaptic density NMDAR1 protein in Home (Saline $100 \pm 8.0$, Cocaine $77.7 \pm 7.6 ; \mathrm{t}(18)=2.027, \mathrm{p}=0.058$ ) and Box groups (Saline $100 \pm 16.5$, Cocaine $70.4 \pm 6.9 ; t(15)=1.727, p=0.105)$ (Figure 2). 
NOT THE PUBLISHED VERSION; this is the author's final, peer-reviewed manuscript. The published version may be accessed by following the link in the citation at the bottom of the page.

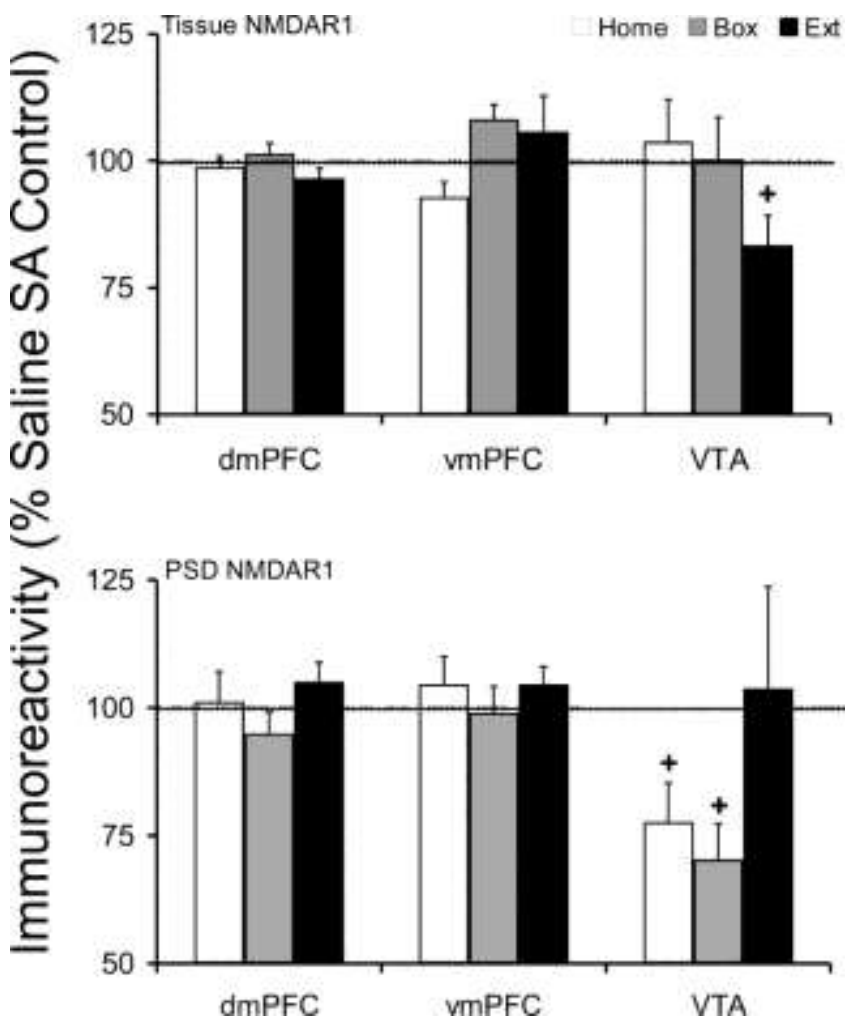

Figure 2 Tissue and postsynaptic density (synaptosomal membrane fraction) levels of NMDAR1 protein after cocaine self-administration and Home, Box, and Extinction treatments. See Figure 1 legend for details. At the tissue level, VTA Extinction group showed near significant reduction in NMDAR1 protein $(p=0.054)$, while mPFC was not changed. The PSD NMDAR1 protein levels in VTA displayed a near significant reduction in both Home $(p=0.058)$ and Box $(p=0.105)$ groups, while mPFC was not changed. + compared to respective saline control.

\subsection{3. mGluR5 and Homer Proteins}

Previous reports have shown that metabotropic glutamate receptors are present as monomer and dimer proteins in the brain tissue and in this study we examined both forms of the receptor after cocaine self-administration (Testa et al., 1998; Schaffhauser et al., 2000).

The VMPFC and VTA did not show any changes in either tissue or postsynaptic density mGluR5 protein levels in cocaine versus corresponding saline control groups (Figure 3 ).

[Citation: Journal/Monograph Title, Vol. XX, No. X (yyyy): pg. XX-XX. DOI. This article is @ [Publisher's Name] and permission has been granted for this version to appear in e-Publications@Marquette. [Publisher] does not grant permission for this article to be further copied/distributed or hosted elsewhere without the express permission from [Publisher].] 


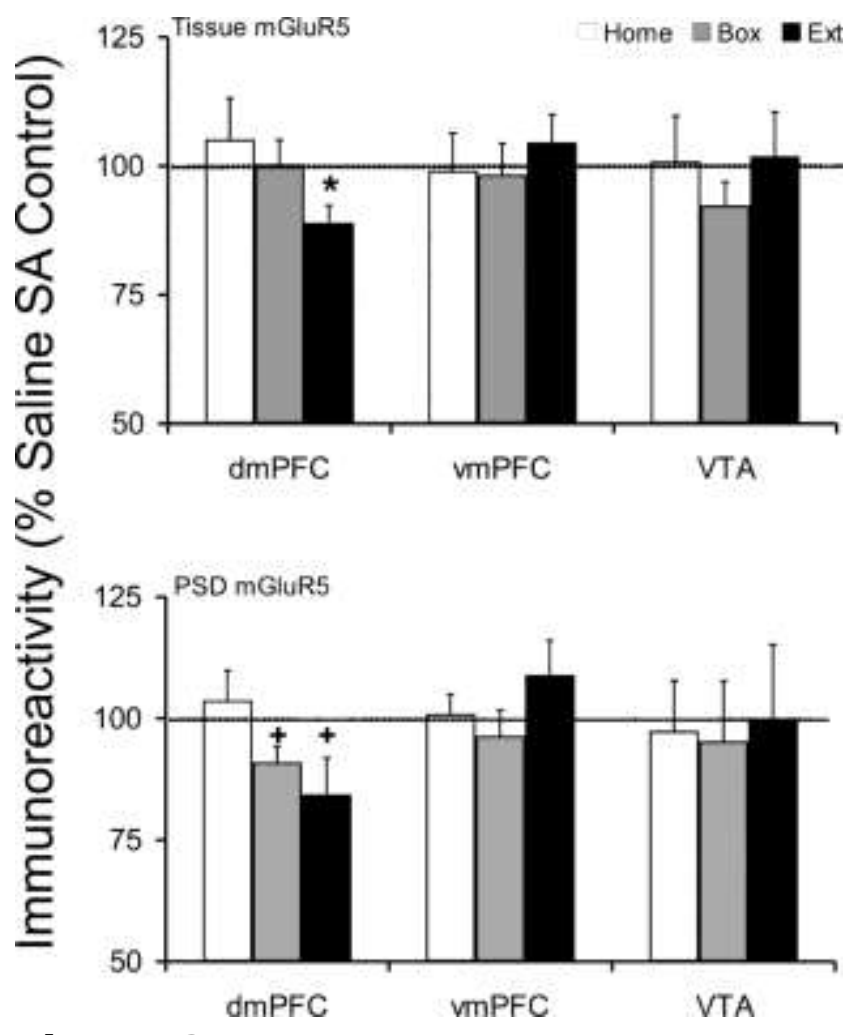

\section{Figure 3}

Tissue and postsynaptic density (synaptosomal membrane fraction) levels of mGluR5 protein after cocaine self-administration and Home, Box, and Extinction treatments. See Figure 1 legend for details. Since both mGluR5 monomer and dimer proteins showed the same trend in tissue and postsynaptic density plasticity in cocaine selfadministrating animals we have only shown the data for the monomer protein. At the tissue level, dmPFC Extinction group showed a significant reduction. Moreover, in PSD, both Box $(p=0.055)$ and Extinction $(p=0.076)$ groups showed near significant reduction in mGluR5 protein. ${ }^{*} \mathrm{p}<0.05$ compared to respective saline control. + compared to respective saline control.

Tissue expression of mGluR5 monomer and dimer proteins in dmPFC were modulated after extinction from cocaine selfadministration (mGluR5m, Saline $100 \pm 3.7$, Cocaine $89.0 \pm 3.4$; $\mathrm{t}(17)=2.183, \mathrm{p}=0.043 ;$ mGluR5d, Saline $100 \pm 5.7$, Cocaine $79.7 \pm$ $9.1 ; \mathrm{t}(16)=1.889, \mathrm{p}=0.077)$; however, there were no changes in Home or Box treatment groups (Figure 3 ). The postsynaptic density mGluR5 protein in dmPFC was also decreased in Extinction animals (mGluR5m, Saline $100 \pm 3.9$, Cocaine $84.4 \pm 7.5 ; \mathrm{t}(15)=1.903$, $\mathrm{p}=0.076$; mGluR5d, Saline $100 \pm 11.4$, Cocaine $70.5 \pm 7.6$; $\mathrm{t}(17)=2.102, \mathrm{p}=0.051)$. Similarly, there was a near significant decrease in postsynaptic density mGluR5 protein in Box animals 
(mGluR5m, Saline $100 \pm 2.8$, Cocaine $91 \pm 3.3 ; \mathrm{t}(17)=2.059$, $\mathrm{p}=0.055 ;$ mGluR5d, Saline $100 \pm 6.7$, Cocaine $87.8 \pm 7.3$; $t(13)=1.234, p=0.238)$. Comparison of saline or cocaine treated animals across withdrawal treatments did not show any changes in tissue mGluR5 monomer and dimer proteins in dmPFC or vmPFC.

Comparing dmPFC PSD mGluR5 protein in saline animals, there were significant changes in mGluR5 monomer, but not dimer, protein (Home $100 \pm 7.5$, Box $124.4 \pm 5.6$, Extinction $97.7 \pm 6.7$; $F(2,22)=4.897, p=0.017)$. Fisher's PLSD post hoc analysis showed that there were significant differences between Home and Box $(p=0.018)$ and Extinction and $\operatorname{Box}(p=0.009)$ but there was no difference between the PSD mGluR5 protein in Home and Extinction saline animals $(p=0.805)$. Since there was no difference between Home and Extinction groups, we compared cocaine treated groups across withdrawal treatments. In cocaine self-administering groups, one-way ANOVA showed a significant trend in dmPFC PSD mGluR5 monomer and dimer proteins across withdrawal treatments (mGluR5m, $F(2,24)=2.85, p=0.077$; mGluR5d, $F(2,24)=2.767, p=0.083)$. Fisher's PLSD post hoc analysis showed that there was a significant difference in Extinction compared to Home animals (mGluR5m, $p=0.029$; mGluR5d, $p=0.030)$. Since both mGluR5 monomer and dimer proteins showed the same trend in tissue and postsynaptic density plasticity in cocaine self-administrating animals we have only shown the data for the monomer protein in Figure 3.

Similarly, comparing vmPFC PSD mGluR5 protein in saline animals, there were significant changes in mGluR5 monomer, but not dimer, protein (Home $100 \pm 5.5$, Box $123.0 \pm 7.0$, Extinction $90.8 \pm$ 7.7; $F(2,22)=5.880, p=0.009$; Home vs. Box, $p=0.023$; Extinction vs. Box, $p=0.003$; Home vs. Extinction, $p=0.342)$. However, there was no difference in vmPFC PSD mGluR5 among cocaine treated groups (Figure 3).

There were no changes in Homer proteins in any of the treatment groups (Supplementary Figure 4S).

[Citation: Journal/Monograph Title, Vol. XX, No. X (yyyy): pg. XX-XX. DOI. This article is @ [Publisher's Name] and permission has been granted for this version to appear in e-Publications@Marquette. [Publisher] does not grant permission for this article to be further copied/distributed or hosted elsewhere without the express permission from [Publisher].] 


\subsubsection{PSD95 Protein}

There was no change in the dmPFC tissue level of PSD95 protein. However, there was a significant increase in dmPFC postsynaptic density level of PSD95 protein in Extinction animals (saline $100 \pm 4.4$, Cocaine $121.2 \pm 6.8 ; \mathrm{t}(16)=-2.609, \mathrm{p}=0.019$ ) (Figure 4). Comparison cocaine treated groups, there was no difference across withdrawal treatments $(F(2,27)=1.820, p=0.181)$. Furthermore, there were no changes in PSD95 protein levels in vmPFC and VTA in any treatment group.

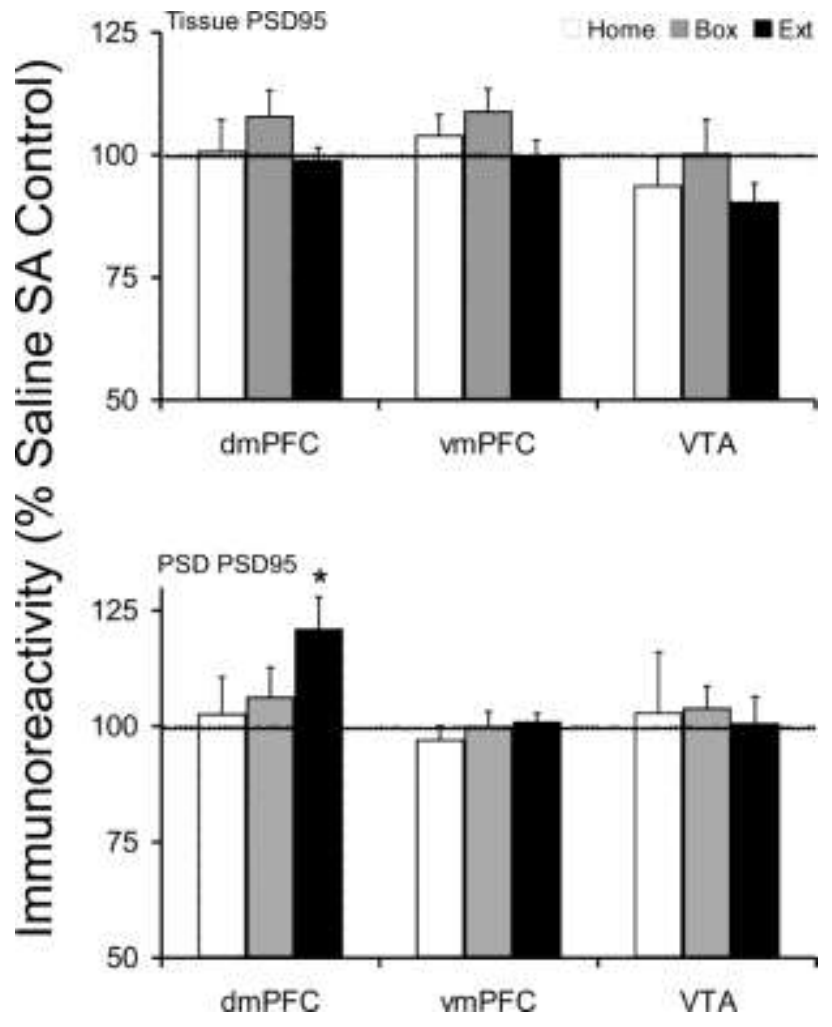

Figure 4 Tissue and postsynaptic density (synaptosomal membrane fraction) levels of PSD95 protein after cocaine self-administration and Home, Box, and Extinction treatments. See Figure 1 legend for details. The tissue level of PSD95 protein was not changed following any post-SA treatment. However, the dmPFC PSD compartment in the Extinction group showed a significant increase in PSD95 protein. ${ }^{*} p<0.05$ compared to respective saline control.

\subsubsection{Actin protein}

There was no change in dmPFC tissue levels of Actin in any treatment group compared to corresponding saline control groups.

[Citation: Journal/Monograph Title, Vol. XX, No. X (yyyy): pg. XX-XX. DOI. This article is @ [Publisher's Name] and permission has been granted for this version to appear in e-Publications@Marquette. [Publisher] does not grant permission for this article to be further copied/distributed or hosted elsewhere without the express permission from [Publisher].] 
However, there was a decreasing trend in dmPFC tissue Actin across cocaine treated animals which did not reach statistical significance $(F(2,23)=1.420, p=0.262)$. There was a significant increase in dmPFC PSD Actin protein in Extinction animals (Saline $100 \pm 6.1$, Cocaine $124.6 \pm 6.2 ; \mathrm{t}(16)=-2.786, \mathrm{p}=0.013)$. Comparing cocaine animals across withdrawal treatments, a trend was seen in PSD Actin protein level in dmPFC which did not reach significance $(F(2,25)=2.084$, $\mathrm{p}=0.146)$. In addition, a significant increase was observed in vmPFC PSD Actin protein in Box animals (Saline $100 \pm 5.1$, Cocaine $126.6 \pm$ $7.9 ; \mathrm{t}(16)=-2.661, \mathrm{p}=0.017$ ) (Figure 5). Moreover, there was a significant effect of withdrawal treatment in vmPFC PSD actin protein level $(F(2,26)=4.354, p=0.023)$. Fisher's PLSD post hoc analysis showed a significant difference between Box and Home $(p=0.0085)$ and between Extinction and Home groups $(p=0.0431)$.

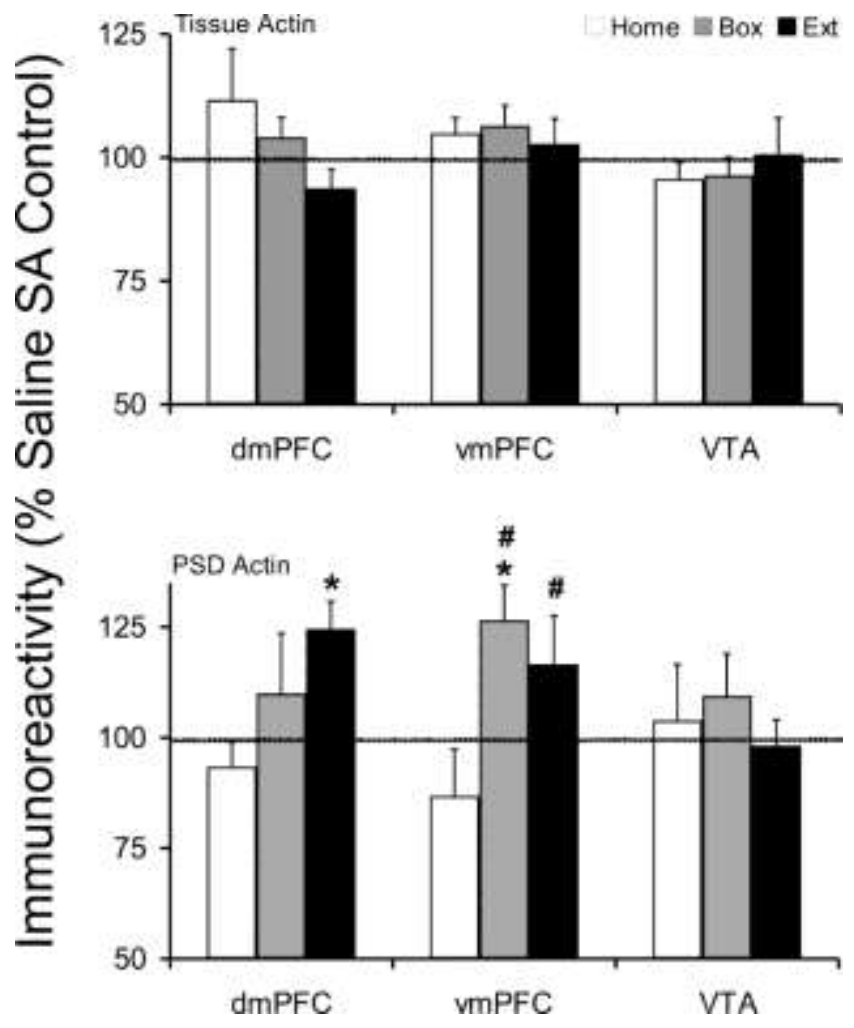

Figure 5 Tissue and postsynaptic density (synaptosomal membrane fraction) levels of Actin protein after cocaine self-administration and Home, Box, and Extinction treatments. See Figure 1 legend for details. The tissue Actin protein was not changed following any post-SA treatment. However, dmPFC Extinction and vmPFC Box groups showed a significant increase in PSD Actin protein. Comparing cocaine selfadministration groups across post-SA conditions, Actin levels were significantly higher

[Citation: Journal/Monograph Title, Vol. XX, No. X (yyyy): pg. XX-XX. DOI. This article is @ [Publisher's Name] and permission has been granted for this version to appear in e-Publications@Marquette. [Publisher] does not grant permission for this article to be further copied/distributed or hosted elsewhere without the express permission from [Publisher].] 
in vmPFC Box and Extinction groups compared to Home group. *p $<0.05$ compared to respective saline control. $\# p<0.05$ compared to Home cocaine group.

There was no change in tissue or postsynaptic density Actin protein levels in VTA under any withdrawal treatments.

\subsubsection{PICK1 protein}

There were significant increases in vmPFC tissue (Saline $100 \pm$ 3.3, Cocaine $112.6 \pm 4.3 ; \mathrm{t}(18)=-2.226, \mathrm{p}=0.039$ ) and PSD (Saline $100 \pm 5.6$, Cocaine $118.6 \pm 5.9, \mathrm{t}(18)=-2.235, \mathrm{p}=0.038)$ PICK1 protein levels in Box animals (Supplementary Figure 5S). In cocaine self-administering groups, tissue PICK1 levels were near significantly affected $(F(2,28)=3.225, p=0.055)$ in vmPFC and post hoc analysis showed that there was a significant increase in Box compared to Home animals $(p=0.0182)$. The PSD level of PICK1 protein in vmPFC was significantly affected in cocaine treated animals across withdrawal treatments $(F(2,26)=3.534, p=0.044)$. Fisher's PLSD post hoc analysis indicated that there was a significant increase in Box compared to Home groups $(p=0.015)$. The PICK1 protein levels in dmPFC and VTA were not affected in any treatment groups (Supplementary Figure 5S).

\section{Discussion}

In this study, we investigated the expression and postsynaptic density (PSD) distribution of glutamate receptors in MPFC and VTA following three distinct withdrawal regimens after two weeks of extended-access cocaine self-administration. Recent studies indicate that MPFC and VTA play pivotal roles in drug reinforcement and seeking and that glutamatergic neurotransmission is an integral part of their contributions to these effects (Kalivas, 2008; Rebec and Sun, 2005; Van den Oever, et al., 2010; Wise, 2009). Of the regions examined, only the dmPFC displayed significant plasticity in glutamate receptors. Amongst withdrawal regimens, extinction training was associated with most plasticity in glutamate receptor expression and redistribution in postsynaptic density, which was associated with extinguished drug-seeking behavior. Home animals which experienced 10 days of forced-abstinence following cocaine self-administration displayed the least amount of change in glutamate receptor expression or trafficking while displaying the highest level of drug-seeking permission has been granted for this version to appear in e-Publications@Marquette. [Publisher] does not grant permission for this article to be further copied/distributed or hosted elsewhere without the express permission from [Publisher].] 
behavior. The data suggest that extinction of drug-seeking behavior is associated with receptor- and region-specific alterations in glutamatergic signaling in MPFC and VTA. Furthermore, region-specific alterations suggest a dichotomy between dorsal versus ventral medial prefrontal cortex regarding drug seeking and extinction. Overall, the results of this study and others support the hypothesis that glutamatergic plasticity is a key factor associated with alteration of established drug taking and seeking-behaviors.

\section{Plasticity in glutamate receptors in medial prefrontal cortex}

The glutamatergic plasticity in dmPFC was specifically associated with the extinction of drug-seek behavior since Home animals did not show any changes in glutamatergic proteins in tissue or PSD compartment. The lack of change in the glutamatergic protein expression in Home group is in agreement with previous studies showing a lack of change in NMDA receptor binding, or NMDAR1, NMDAR2A, mGluR1, mGluR5, Homer1b/c, Homer2a/b mRNA or protein levels in dmPFC after 14 days of Home treatment (Tang et al., 2004; Ben-Shahar et al., 2007, 2009; Freeman et al., 2008). However, an increase in tissue NMDAR2B protein has been shown after 14 days of Home treatment (Tang et al., 2004; Ben-Shahar et al., 2009). There was a decrease in postsynaptic density mGluR5 protein in Box group; however, these animals also experienced partial extinction of drug seeking. The AMPA receptor subunit GluR1 and associated postsynaptic scaffolding proteins PSD95 and actin showed a significant redistribution into the postsynaptic density after extinction training; while tissue GluR1 protein was not changed in agreement with recent studies (Tang et al., 2004; Hemby et al., 2005). In contrast, in Extinction animals, NMDA receptor subunit NMDAR1 was not changed and mGluR5 receptor was reduced in postsynaptic density. It is interesting to note that the three subtypes of glutamate receptors examined in these studies showed unique pattern of plasticity in dmPFC after extinction of drug seeking suggesting receptor-specific role in extinction of drug seeking. A functional role for the increase in PSD level of GluR1 protein is supported by simultaneous increases in PSD95 and actin proteins. The PSD95 protein is found in the postsynaptic density and regulates membrane insertion of AMPA

[Citation: Journal/Monograph Title, Vol. XX, No. X (yyyy): pg. XX-XX. DOI. This article is @ [Publisher's Name] and permission has been granted for this version to appear in e-Publications@Marquette. [Publisher] does not grant permission for this article to be further copied/distributed or hosted elsewhere without the express permission from [Publisher].] 
receptors, as well as their interactions with the postsynaptic density (Hunt et al., 1996; Tu et al., 1999; Schnell at al., 2002; El-Husseini et al., 2000). Actin is also involved in regulation of AMPA receptor synaptic insertion, removal, and intracellular recycling of the receptor (Allison et al., 1998; Kim and Lisman, 1999; Shen et al., 2000). Recent studies suggest that, one day after extended-access cocaine self-administration, the dmPFC tissue level of AMPA receptor subunits GluR2/3 and GluR4 decrease while GluR1 is not changed. However, after 14 days of abstinence, while GluR1 level is not changed, GluR2/3 is normalized and GluR4 is significantly increased (Tank et al., 2004; Hemby et al., 2005). Therefore, while cocaine reinforcing effects may be associated with the prominent presence of GluR1 containing AMPA receptors in dmPFC, abstinence from cocaine self-administration may be associated with increased presence of GluR2/3/4 subunits in GluR1 containing receptors. In contrast, GluR1 plasticity in dmPFC is selectively associated with extinction learning. In support, learning tasks lead to increased synaptic GluR1 protein and manipulations that enhance learning augment synaptic GluR1 levels (Chen et al., 2011; Whitlock et al., 2006; Slipczuk et al., 2009). Furthermore, GluR1 KO mice show diminished learning during extinction training (Mead et al., 2007).

The metabotropic glutamate receptor mGluR5 showed decreases in both tissue and postsynaptic density compartment suggesting an overall decrease in mGluR5 receptor function in dmPFC of Extinction animals. A role for decreased mGluR5 receptor signaling after extinction of drug seeking is supported by studies showing that mGluR5 receptor antagonists or mGluR5 receptor knock down reduce relapse to cocaine seeking (Kumaresan et al., 2009; Backstrom and Hyytia, 2006; Martin-Fardon et al., 2009; Novak et al., 2010). In addition, mGluR5 knockout mice do not self-administer cocaine suggesting a pivotal role for mGluR5 in reinforcing effects of cocaine (Chiamulera et al., 2001). Further, positive allosteric modulators of mGluR5 receptor facilitate extinction of cocaine conditioned preference, which may be due to receptor desensitization following repeated activation (Gass and Olive, 2009; Dhami and Ferguson, 2006; Ribeiro et al., 2009; Cleva et al., 2011). Interestingly, PSD mGluR5 protein in nucleus accumbens is also reduced after extinction of cocaine self-administration, which along with a reduced tone on mGluR5 receptors may be responsible for diminished capacity to permission has been granted for this version to appear in e-Publications@Marquette. [Publisher] does not grant permission for this article to be further copied/distributed or hosted elsewhere without the express permission from [Publisher].] 
induce LTD in nucleus accumbens (Martin et al., 2006; Ghasemzadeh et al., 2009a; Moussawi et al., 2009; Kalivas, 2009). Taken together, these data suggest that mGluR5 decrease in dmPFC PSD after extinction training is a compensatory plasticity contributing to reduce cocaine seeking.

Our data indicate a concurrent reduction in mGluR5 and an increase in GluR1 proteins in dmPFC (this study) and NAshell PSD (Ghasemzadeh et al., 2009a) in extinction animals. These observations suggest a functional relationship between the two glutamate receptor subtypes in mediating plasticity which may have relevance to drug seeking. In support, activation of mGluR5 signaling leads to GluR1 internalization in vitro an in vivo (Zhang et al., 2008). For example, mGluR5-mediated LTD is associated with GluR1 endocytosis (Gladding et al., 2009). Recent studies have indicated that repeated noncontingent cocaine administration or cocaine self-administration leads to disruption of mGluR5-dependent LTD in nucleus accumbens, which may lead to an increase in synaptic insertion of GluR1 protein (Martin et al., 2006; Kalivas, 2009; Moussawi et al., 2009, 2011). Akin to nucleus accumbens, dmPFC expresses mGuR5-dependent LTD upon low frequency stimulation (Lafourcade et al., 2007; Otani et al., 1999). Therefore, it is tempting to hypothesize that extinction of cocaine selfadministration leads to decreased synaptic mGluR5 and disruption of LTD in dmPFC resulting in increased trafficking of GluR1 protein to postsynaptic density compartment.

There were few changes in glutamatergic proteins in vmPFC. The tissue NMDAR1 subunit protein in vmPFC of Home animals showed a decreasing trend that did not reach significance $(p=0.098)$. Surprisingly, there were significant increases in tissue and synaptosomal level of PICK1 protein in vmPFC of Box animals. This was the only change in PICK1 protein that was observed in PFC and VTA in this study. Box animals are exposed to a new condition during withdrawal period where contextual cues (self-administration box) are present in the absence of discrete cues (levers are withdrawn); therefore, the changes in PICK1 protein may represent the plasticity associated with learning in this new environment. It is interesting to note that plasticity in nucleus accumbens PICK1 proteins was also associated with the Box withdrawal regimen (Ghasemzadeh et al., 2009a).

[Citation: Journal/Monograph Title, Vol. XX, No. X (yyyy): pg. XX-XX. DOI. This article is @ [Publisher's Name] and permission has been granted for this version to appear in e-Publications@Marquette. [Publisher] does not grant permission for this article to be further copied/distributed or hosted elsewhere without the express permission from [Publisher].] 
Actin protein was increased in vmPFC PSD of Box and in dmPFC PSD of Extinction animals, as mentioned above. Furthermore, we have previously shown that actin protein is significantly increased in the dorsolateral striatum PSD of Extinction animals (Ghasemzadeh et al., $2009 b)$. An increase in actin protein in the synaptosomal fraction or dendritic spines has been associated with enlarged synapse and spine size (Lisman, 2003) and has been documented after repeated exposure to cocaine (Toda et al., 2006). Furthermore, synaptic actin is associated with trafficking and synaptic localization of GluR1 protein and LTP (Lisman, 2003). These observations are in general agreement with our data indicating that increased PSD actin may be associated with increased synaptic GluR1 protein and increased spine density observed after cocaine self-administration (Robinson et al., 2001).

Recent studies indicate that chronic exposure to cocaine leads to diminished cortical activity, frontal cortical glucose metabolism, gray matter density, and cognitive decline in both human addicts and animal models of addiction (London et al., 1999; Volkow and Fowler, 2000; Franklin et al., 2002; Matochik et al., 2003; Bolla et al., 2003; Briand et al., 2008; George et al., 2008; Beveridge et al., 2006). An increase in AMPA receptor function suggested by increased trafficking of GluR1 and associated synaptic proteins to postsynaptic density in prefrontal cortex and nucleus accumbens observed with extinction training may lead to an increase in cortical and accumbal excitatory neurotransmission alleviating drug-seeking behaviors (Sutton et al., 2003; Ghasemzadeh et al., 2009a). In support, synaptic GluR1 is associated with extinction learning and GluR1 knockout mice show more persistent drug seeking (Chen et al., 2011; Mead et al., 2007; Whitlock et al., 2006; Slipczuk et al., 2009). Moreover, inactivation of or synaptic depression in vmPFC reinstates drug seeking after extinction and blockade of mGluR5 receptors reduce drug-seeking reinstatement (Peters et al., 2008; Kumaresan et al., 2009; Van den Oever et al., 2008). Thus, the increased PSD GluR1 in prefrontal cortex and nucleus accumbens concurrent with decreased mGluR5 in both nuclei following extinction of drug seeking may be compensatory plasticity in the glutamatergic signaling to resist addiction through reduced drug seeking and increased cognition.

Lastly, differential plasticity in glutamatergic proteins in dorsal versus ventral mPFC mirrors their distinct functional roles in drug permission has been granted for this version to appear in e-Publications@Marquette. [Publisher] does not grant permission for this article to be further copied/distributed or hosted elsewhere without the express permission from [Publisher].] 
seeking. Whereas dorsal compartment is implicated in promotion of drug-seeking behavior, ventral region plays a pivotal role in inhibition of drug seeking (Lasseter et al., 2010; Van den Oever, et al., 2010; Peters et al., 2008, 2009). Therefore, distinct glutamatergic plasticity in each compartment may contribute to respective functional roles.

\section{Glutamate receptor plasticity in ventral tegmental area}

VTA plays an important role in drug seeking behavior (Wise, 2009). Blockade of dopamine or glutamate receptors in VTA reduces drug-seeking behavior (Sun et al., 2005a). In agreement with a recent study showing diminished NMDA receptor EPSC in VTA neurons after cocaine treatment (Mameli et al., 2011), the VTA displayed a decrease in NMDAR1 protein that was observed across all three withdrawal regimen. While Home and Box groups displayed a decrease in PSD NMDAR1 protein, the Extinction group showed a decrease in tissue level of NMDAR1 protein without a change in PSD protein. Therefore, it seems that Extinction treatment reversed Home and Box induced decrease in PSD NMDAR1 protein while a decrease in tissue level of NMDAR1 proteins emerged. The decrease in PSD NMDAR1 protein in Home and Box groups may be a compensatory plasticity to regulate drug seeking since the blockade of glutamate receptors in VTA reduce cocaine-primed drug seeking (Sun et al., 2005a). Likewise, the PSD NMDAR1 protein normalized once drug seeking has been extinguished. There was no change in other proteins examined in VTA in any withdrawal treatment groups. In support of our VTA data, other studies using similar cocaine self-administration and Home withdrawal conditions have shown no changes in NMDA receptor binding, NMDAR1 tissue protein, tissue and membrane GluR1 protein, or tissue levels of mGluR5 and Homer1b/c proteins (Tang et al., 2004; Ben-Shahar et al., 2007, 2009; Conrad et al., 2008). However, one study has shown an increase in VTA tissue NMDAR1 protein up to 90 days after cocaine self-administration (Lu et al., 2003).

In summary, our data indicate that there are withdrawal-, receptor- and region-specific plasticity in glutamategic proteins in prefrontal cortex and ventral tegmental area, which suggest that significant alterations in glutamatergic signaling underlie the behavioral adaptations and cognitive deficits associated with drug 
addiction. Combined with glutamatergic plasticity reported in nucleus accumbens, these data suggest that addiction-related behaviors are associated with a complex pattern of plasticity in excitatory signaling in the brain, which await further characterization (Sutton et al., 2003; Conrad et al., 2008; Anderson et al., 2008; Ghasemzadeh et al., 2009a,b).

\section{Materials and Methods}

\subsection{Subjects}

Seventy-five adult male Sprague-Dawley rats (Harlan Laboratories, Inc., St. Louis, MO), approximately 90 days old (325 g) were used for the study. Rats were housed individually in a temperature- and humidity-controlled, AAALAC-accredited animal facility under a $12 \mathrm{~h} / 12 \mathrm{~h}$ reversed light/dark cycle (lights on at 18:00) and had access to food at all times, except when in the experimental chambers. Water was available at all times during the study, including in the experimental chambers. All procedures were carried out in accordance with the Guide for the Care and Use of Laboratory Animals as adopted and promulgated by the NIH.

\subsection{Cocaine Self-Administration Training}

The catheterization surgery and self-administration training have been described in detail previously (Ghasemzadeh et al., 2009a); a detailed description of materials and methods is included as supplementary information. Briefly, rats were implanted with chronic indwelling catheters into the jugular vein. The guide cannula was located on the animal's back where it permitted connection of a polyethylene delivery line. Rats were allowed to recover for at least three days prior to self-administration training. Twenty operant conditioning chambers encased in sound attenuating cubicles (MedAssociates Inc., St Albans, VT) were used. Rats were trained to selfadminister cocaine $(1.0 \mathrm{mg} / \mathrm{kg} / \mathrm{inf}, 200 \mu \mathrm{l}, 5$ seconds, iv, NIDA, Bethesda, MD) or provided access to saline solution by pressing a lever under a FR1 schedule during daily 2 -h sessions. Once a stable response pattern was observed during the 2 -h sessions, the duration of daily cocaine/saline access was increased to 6 hrs which continued

[Citation: Journal/Monograph Title, Vol. XX, No. X (yyyy): pg. XX-XX. DOI. This article is @ [Publisher's Name] and permission has been granted for this version to appear in e-Publications@Marquette. [Publisher] does not grant permission for this article to be further copied/distributed or hosted elsewhere without the express permission from [Publisher].] 
for 14 days prior to exposure to home cage (Home), SA box (Box), or extinction (Ext) conditions after self-administration period.

\subsection{Withdrawal conditions following cocaine self- administration (Post-SA)}

Cocaine and saline self-administration rats were exposed to one of three conditions (Home, Box, Extinction) during post-SA period. For Extinction rats, the cocaine solution was replaced with saline for 10 consecutive 6-h extinction sessions conducted over a 12-14 day period. Aside from saline rather than cocaine availability, these sessions were otherwise identical to the self-administration sessions. Saline Extinction rats continued to have access to saline during these ten sessions. For the other two conditions rats did not undergo extinction during the Post-SA period, but rather remained in their home cages (Home rats, 10 days) or were introduced into the selfadministration boxes for $6 \mathrm{hr}$ each day with the levers retracted and stimulus lights extinguished (Box rats, 10 days).

\subsection{Cocaine-seeking behavior}

Cocaine-seeking behavior was recorded in six Home rats, eight Box rats, and ten Extinction rats. For the Home and Box rats, cocaine seeking was measured during a 6 -h session within which lever pressing resulted in saline infusions conducted after a 12-14 day postSA period during which they remained in their home cages (Home rats) or were introduced into the SA boxes for six hrs each day with the levers retracted and stimulus lights extinguished (Box rats). For Extinction rats, data collected during the final 6-h extinction session (i.e., extinction day 10) were used for comparison. The Home and Box rats in which cocaine seeking was measured were not used for protein determination.

\subsection{Anatomical dissection and Biochemical Subcellular Fractionation}

At the end of the post-SA period, Home, Box, and Extinction rats were decapitated, brains quickly removed, areas of interest dissected, immediately frozen on dry ice, and stored at $-80^{\circ} \mathrm{C}$. The

[Citation: Journal/Monograph Title, Vol. XX, No. X (yyyy): pg. XX-XX. DOI. This article is @ [Publisher's Name] and permission has been granted for this version to appear in e-Publications@Marquette. [Publisher] does not grant permission for this article to be further copied/distributed or hosted elsewhere without the express permission from [Publisher].] 
medial prefrontal cortex (mPFC) was blocked between plates 6 and 11 (Bregma 5.16-3.00 mm) (paxinos and Watson, 2005). The dorsal and ventral PFC border was set at the middle of prelimbic cortex based on previous anatomical and functional studies (Heidbreder and Groenewegen, 2003) and was hand dissected. The ventral tegmental area was blocked between plates 77-85 (Bregma -5.28-6.24 mm) and was hand dissected (Supplementary figure 1 ). The membrane preparation and biochemical fractionation were based on methods by Dunah and Standaert (2001) and Toda et al, (2003) and has been described in detail previously (Ghasemzadeh et al., 2009a). A schematic of the membrane purification procedure, adopted from Dunah and Standaert (2001), is presented in Supplementary figure 1.

\subsection{Western Blot Analysis}

Two independent protein analyses were performed. In the first analysis, all saline-treated animals ( $n=10$ per post-SA treatment group) were compared across post-SA conditions. This was done to identify any effects of post-SA conditions that were independent of cocaine exposure. The second analysis compared cocaine-treated animals to their corresponding saline control group for each post-SA treatment (i.e., the mean percent change resulting from cocaine selfadministration was determined based on values for saline samples on the same gel). Due to the large number of samples, each of the three comparisons (10 saline and 10 cocaine for each post-SA treatment) was done separately.

Western Blot procedures have been described in detail previously (Ghasemzadeh et al., 2009a; Ghasemzadeh et al., 2003). Protein samples ( $6 \mu \mathrm{g} /$ lane) were resolved by SDS-PAGE and transferred to a polyvinyldine fluoride (PVDF) membrane. Membranes were blocked for $2 \mathrm{hrs}$ at room temperature and incubated with commercially obtained primary antibody overnight at $4{ }^{\circ} \mathrm{C}$, washed and incubated with HRP-conjugated secondary antibody for 90 minutes at room temperature. Membranes were washed and immunolabeling was visualized with enhanced chemiluminescence (ECL method) using a Kodak Image Station 4000MM. Band density was measured using Kodak Molecular Imaging Software v4.0. The following primary antibodies were used in this study: mouse NMDAR1 (Millipore, Cat. \# 
05-432, 1:3000 dilution), rabbit GluR1 (Millipore, Cat. \# 07-660, $1: 10,000$ dilution), rabbit mGluR5 (Millipore, Cat. \# 06-451, 1:10,000 dilution), mouse PSD95 (Antibodies Inc., Cat. \# 75-028, 1:10,000 dilution), mouse PICK1 (Antibodies Inc., Cat. \# 75-040, 1:3000 dilution), rabbit Homer1b/c (Santa Cruz Biotech, Cat. \# sc-20807, 1:3000 dilution), goat Actin (Santa Cruz Biotech, Cat. \# sc-1615, $1: 10,000)$. The following HRP-conjugated secondary antibodies were used: goat anti-rabbit IgG (Millipore, Cat. \# 12-348, 1:20,000 dilution), goat anti-mouse IgG (Millipore, Cat. \# 12-349, 1:20,000 dilution).

\subsection{Statistics}

The self-administration data (infusions/session) were evaluated using two-way ANOVA with repeated measures over sessions. Responding on test day (infusions/session) was compared using oneway ANOVA comparing the three post-SA treatment groups. In both cases, differences between groups were determined using post hoc Fisher's PLSD. For analysis of cocaine self-administration induced alterations in protein levels under each of the three post-SA conditions, immunoreactivity of protein samples from cocaine and saline rats was normalized as percent change relative to the respective mean saline control values for samples on the same gel. Normalized saline and cocaine values were then compared separately for each post-SA condition using Student's t-tests. To permit comparison of cocaine-induced changes across post-SA treatment conditions, saline self-administration effects on protein levels determined from a separate protein analysis were initially compared across post-SA conditions using one-way ANOVA followed by the Fisher's PLSD test to identify any effects of post-SA conditions that were independent of cocaine exposure. For this analysis saline self-administration induced protein alterations under each of the post-SA conditions were normalized as percent change relative to the respective mean Home sample saline values determined from the same gel. In cases where there were no differences following saline exposure across post-SA conditions, percent changes in protein following cocaine selfadministration were compared across post-SA conditions using oneway ANOVA, followed by post-hoc testing using the Fisher's PLSD test. Statistical significance was set at $p<0.05$. 
NOT THE PUBLISHED VERSION; this is the author's final, peer-reviewed manuscript. The published version may be accessed by following the link in the citation at the bottom of the page.

\section{Highlights}

- We examined glutamate receptor plasticity in extended-access cocaine self-administration (SA) animal model of addiction.

- Following cocaine self-administration, animals either stayed in home cages (abstinence) or lever pressing was extinguished.

- The postsynaptic density (PSD) NMDAR1 protein in VTA was decreased after abstinence but not extinction.

- An increase in PSD GluR1, PSD95, Actin and a decrease in mGluR5 receptor proteins were observed following extinction of SA.

- The glutamate receptor plasticity in PFC and VTA was region- and withdrawal-dependent.

\section{Acknowledgments}

This work was supported by NIH/NIDA Grant numbers DA14328 (MBG) and DA15758 (JRM). The generous gift of cocaine by NIH/NIDA is gratefully acknowledged.

\section{Footnotes}

Publisher's Disclaimer: This is a PDF file of an unedited manuscript that has been accepted for publication. As a service to our customers we are providing this early version of the manuscript. The manuscript will undergo copyediting, typesetting, and review of the resulting proof before it is published in its final citable form. Please note that during the production process errors may be discovered which could affect the content, and all legal disclaimers that apply to the journal pertain.

\section{References}

Allison DW, Gelfand VI, Spector I, Craig AM. Role of actin in anchoring postsynaptic receptors in cultured hippocampal neurons: differential attachment of NMDA versus AMPA receptors. J Neurosci. 1998;18:2423-2436.

Anderson SM, Famous KR, Sadri-Vakili G, Kumaresan V, Schmidt HD, Bass CE, Terwilliger EF, Cha JH, Pierce RC. CaMKII: a biochemical bridge linking accumbens dopamine and glutamate systems in cocaine seeking. Nat Neurosci. 2008;11:344-353. 
Bäckström P, Hyytiä P. Ionotropic and metabotropic glutamate receptor antagonism attenuates cue-induced cocaine seeking. Neuropsychopharmacology. 2006;31:778-786.

Beckstead RM. An autoradiographic examination of corticocortical and subcortical projections of the mediodorsal-projection (prefrontal) cortex in the rat. J Comp Neurol. 1979;184:43-62.

Ben-Shahar O, Keeley P, Cook M, Brake W, Joyce M, Nyffeler M, Heston R, Ettenberg $A$. Changes in levels of D1, D2, or NMDA receptors during withdrawal from brief or extended daily access to IV cocaine. Brain Res. 2007;1131:220-228.

Ben-Shahar O, Obara I, Ary AW, Ma N, Mangiardi MA, Medina RL, Szumlinski KK. Extended daily access to cocaine results in distinct alterations in Homer $1 \mathrm{~b} / \mathrm{c}$ and NMDA receptor subunit expression within the medial prefrontal cortex. Synapse. 2009;63:598-609.

Berendse HW, Galis-de Graaf Y, Groenewegen HJ. Topographical organization and relationship with ventral striatal compartments of prefrontal corticostriatal projections in the rat. J Comp Neurol. 1992;316:314-347.

Berglind WJ, See RE, Fuchs RA, Ghee SM, Whitfield TW, Jr., Miller SW, McGinty JF. A BDNF infusion into the medial prefrontal cortex suppresses cocaine seeking in rats. Eur J Neurosci. 2007;26(3):757-766.

Beveridge TJ, Smith HR, Daunais JB, Nader MA, Porrino LJ. Chronic cocaine self-administration is associated with altered functional activity in the temporal lobes of non human primates. Eur J Neurosci. 2006;23:3109-3118.

Bolla KI, Eldreth DA, London ED, Kiehl KA, Mouratidis M, Contoreggi C, Matochik JA, Kurian V, Cadet JL, Kimes AS, Funderburk FR, Ernst M. Orbitofrontal cortex dysfunction in abstinent cocaine abusers performing a decision-making task. Neuroimage. 2003;19(3):1085-1094.

[Citation: Journal/Monograph Title, Vol. XX, No. X (yyyy): pg. XX-XX. DOI. This article is @ [Publisher's Name] and permission has been granted for this version to appear in e-Publications@Marquette. [Publisher] does not grant permission for this article to be further copied/distributed or hosted elsewhere without the express permission from [Publisher].] 
Briand LA, Flagel SB, Garcia-Fuster MJ, Watson SJ, Akil H, Sarter M, Robinson TE. Persistent alterations in cognitive function and prefrontal dopamine D2 receptors following extended, but not limited, access to self-administered cocaine.

Neuropsychopharmacology. 2008;33(12):2969-2980.

Brinley-Reed M, Mascagni F, McDonald AJ. Synaptology of prefrontal cortical projections to the basolateral amygdala: an electron microscopic study in the rat. Neurosci Lett. 1995. $1995 ; 202: 45-48$.

Capriles N, Rodaros D, Sorge RE, Stewart J. A role for the prefrontal cortex in stress- and cocaine-induced reinstatement of cocaine seeking in rats. Psychopharmacology (Berl) 2003;168:66-74.

Chen DY, Stern SA, Garcia-Osta A, Saunier-Rebori B, Pollonini G, Bambah-Mukku D, Blitzer RD, Alberini CM. A critical role for IGF-II in memory consolidation and enhancement. Nature. 2011;469:491-497.

Chiamulera C, Epping-Jordan MP, Zocchi A, Marcon C, Cottiny C, Tacconi S, Corsi M, Orzi F, Conquet F. Reinforcing and locomotor stimulant effects of cocaine are absent in mGluR5 null mutant mice. Nat Neurosci. 2001;4:873-874.

Cleva RM, Hicks MP, Gass JT, Wischerath KC, Plasters ET, Widholm J], Olive MF. mGluR5 positive allosteric modulation enhances extinction learning following cocaine self-administration. Behav Neurosci. 2011;125:10-19.

Conde F, Maire-Lepoivre E, Audinat F, Crepel F. Afferent connections of the medial frontal cortex of the rat. II. Cortical and subcortical afferents. J Comp Neurol. 1995;352:567-593.

Conrad KL, Tseng KY, Uejima JL, Reimers JM, Heng LJ, Shaham Y, Marinelli M, Wolf ME. Formation of accumbens GluR2-lacking AMPA receptors mediates incubation of cocaine craving. Nature. 2008;454:118-121.

[Citation: Journal/Monograph Title, Vol. XX, No. X (yyyy): pg. XX-XX. DOI. This article is @ [Publisher's Name] and permission has been granted for this version to appear in e-Publications@Marquette. [Publisher] does not grant permission for this article to be further copied/distributed or hosted elsewhere without the express permission from [Publisher].] 
Cunha PJ, Nicastri S, de Andrade AG, Bolla KI. The frontal assessment battery $(F A B)$ reveals neurocognitive dysfunction in substancedependent individuals in distinct executive domains: Abstract reasoning, motor programming, and cognitive flexibility. Addict Behav. 2010;35(10):875-881.

Derbach VA, Oh MC, Guire ES, Soderling TR. Regulatory mechanisms of AMPA receptors in synaptic plasticity. Nature Rev Neursci. 2007; 8:101-113.

Dhami GK, Ferguson SS. Regulation of metabotropic glutamate receptor signaling, desensitization and endocytosis. Pharmacol Ther. 2006;111:260-271.

Di Pietro NC, Black YD, Kantak KM. Context-dependent prefrontal cortex regulation of cocaine self-administration and reinstatement behaviors in rats. Eur J Neurosci. 2006;24(11):3285-3298.

Dunah AW, Standaert DG. Dopamine D1 receptor-dependent trafficking of striatal NMDA glutamate receptors to the postsynaptic membrane. J Neurosci. 2001;21:5546-5558.

El-Husseini AE, Schnell E, Chetkovich DM, Nicoll RA, Bredt DS. PSD-95 involvement in maturation of excitatory synapses. Science. 2000;290(5495):1364-1368.

Franklin TR, Acton PD, Maldjian JA, Gray JD, Croft JR, Dackis CA, O'Brien CP, Childress AR. Decreased gray matter concentration in the insular, orbitofrontal, cingulate, and temporal cortices of cocaine patients. Biol Psychiatry. 2002;51:134-142.

Freeman WM, Patel KM, Brucklacher RM, Lull ME, Erwin M, Morgan D, Roberts DC, Vrana KE. Persistent alterations in mesolimbic gene expression with abstinence from cocaine selfadministration. Neuropsychopharmacology. 2008;33:18071817.

[Citation: Journal/Monograph Title, Vol. XX, No. X (yyyy): pg. XX-XX. DOI. This article is (C) [Publisher's Name] and permission has been granted for this version to appear in e-Publications@Marquette. [Publisher] does not grant permission for this article to be further copied/distributed or hosted elsewhere without the express permission from [Publisher].] 
Gao C, Wolf ME. Dopamine receptors regulate NMDA receptor surface expression in prefrontal cortex neurons. J Neurochem. 2008;106(6):2489-2501.

Gass JT, Olive MF. Positive allosteric modulation of mGluR5 receptors facilitates extinction of a cocaine contextual memory. Biol Psychiatry. 2009;65:717-720.

George O, Mandyam CD, Wee S, Koob GF. Extended access to cocaine self administration produces long-lasting prefrontal cortexdependent working memory impairments. Neuropsychopharmacology. 2008;33:2474-2482. [

Ghasemzadeh MB, Mueller C, Vasudevan P. Behavioral sensitization to cocaine is associated with increased glutamate receptor trafficking to the postsynaptic density after extended withdrawal period. Neuroscience. 2009c;159(1):414-426.

Ghasemzadeh MB, Permenter LK, Lake R, Worley PF, Kalivas PW. Homer1 Proteins and AMPA receptors modulate cocaineinduced behavioral plasticity. Eur J Neurosci. 2003;18:16451651.

Ghasemzadeh MB, Vasudevan P, Mueller C. Locomotor sensitization to cocaine is associated with distinct pattern of glutamate receptor trafficking to the postsynaptic density in prefrontal cortex: early versus late withdrawal effects. Pharmacol Biochem Behav. 2009d;92:383-392.

Ghasemzadeh MB, Vasudevan P, Mueller C, Seubert C, Mantsch JR. Region specific alterations in glutamate receptor expression and subcellular distribution following extinction of cocaine selfadministration. Brain Res. 2009a;1267:89-102.

Ghasemzadeh MB, Vasudevan P, Mueller C, Seubert C, Mantsch JR. Neuroadaptations in the cellular and postsynaptic group 1 metabotropic glutamate receptor mGluR5 and Homer proteins following extinction of cocaine self-administration. Neurosci Lett. 2009b;452:167-171.

[Citation: Journal/Monograph Title, Vol. XX, No. X (yyyy): pg. XX-XX. DOI. This article is @ [Publisher's Name] and permission has been granted for this version to appear in e-Publications@Marquette. [Publisher] does not grant permission for this article to be further copied/distributed or hosted elsewhere without the express permission from [Publisher].] 
Gladding CM, Collett VJ, Jia Z, Bashir ZI, Collingridge GL, Molnár E. Tyrosine dephosphorylation regulates AMPAR internalisation in mGluR-LTD. Mol Cell Neurosci. 2009;40:267-279.

Goldstein RZ, Volkow ND. Drug addiction and its underlying neurobiological basis: neuroimaging evidence for the involvement of the frontal cortex. Am J Psychiatry. 2002; 159: 1642-1652.

Gorelova NA, Yang CR. The course of neural projection from the prefrontal cortex to the nucleus accumbens in the rat. Neurscience. 1997;76:689-706.

Groenewegen HJ, Berendse HW, Wolters JG, Lohman AHM. The anatomical relationship of the prefrontal cortex with the striatopalidal system, the thalamus, and the amygdala: evidence for a parallel organization. Progr Brain Res. 1990;85:95-116.

Guzman D, Moscarello JM, Ettenberg A. The effects of medial prefrontal cortex infusions of cocaine in a runway model of drug self-administration: evidence of reinforcing but not anxiogenic actions. Eur J Pharmacol. 2009;605(1-3):117-122.

Heidbreder CA, Groenewegen HJ. The medial prefrontal cortex in the rat: evidence for a dorso-ventral distinction based upon functional and anatomical characteristics. Neurosci Biobeh Rev. 2003;27:555-579.

Hemby SE, Horman B, Tang W. Differential regulation of ionotropic glutamate receptor subunits following cocaine selfadministration. Brain Res. 2005;1064:75-82.

Hunt CA, Schenker LJ, Kennedy MB. PSD95 is associated with the postsynaptic density and not with the presynaptic membrane at forebrain synapses. J Neurosci. 1996;16:1380-1388.

Hurley KM, Herbert H, Moga MM, Saper CB. Efferent projections of the infralimbic cortex of the rat. J Comp Neurol. 1991;308:249276.

[Citation: Journal/Monograph Title, Vol. XX, No. X (yyyy): pg. XX-XX. DOI. This article is @ [Publisher's Name] and permission has been granted for this version to appear in e-Publications@Marquette. [Publisher] does not grant permission for this article to be further copied/distributed or hosted elsewhere without the express permission from [Publisher].] 
Kalivas PW. Addiction as a pathology in prefrontal cortical regulation of corticostriatal habit circuitry. Neurotox Res. 2008;14(23):185-189.

Kalivas PW. The glutamate homeostasis hypothesis of addiction. Nat Rev Neurosci. 2009;10:561-572.

Kalivas PW, McFarland K. Brain circuitry and the reinstatement of cocaine-seeking behavior. Psychopharmacology (Berl) 2003; 168:44-56.

Kalivas PW, Volkow ND. The neural basis of addiction: a pathology of motivation and choice. Am J Psychiatry. 2005;162:1403-1413.

Kennedy MB. Signal-processing machines at the postsynaptic density. Science. 2000;290:750-754.

Kennedy MJ, Ehlers MD. Organelles and trafficking machinery for postsynaptic plasticity. Ann Rev Neurosci. 2006;29:325-362.

$\mathrm{Kim} \mathrm{CH}$, Lisman JE. A role of actin filament in synaptic transmission and long-term potentiation. J Neurosci 1999. 1999;19:43144324.

Kreek MJ, Koob GF. Drug dependence: stress and dysregulation of brain reward pathways. Drug Alcohol Depend. 1998;51:23-47.

Kumaresan V, Yuan M, Yee J, Famous KR, Anderson SM, Schmidt HD, Pierce RC. Metabotropic glutamate receptor 5 (mGluR5) antagonists attenuate cocaine priming- and cue-induced reinstatement of cocaine seeking. Behav Brain Res. $2009 ; 202: 238-244$.

Lafourcade M, Elezgarai I, Mato S, Bakiri Y, Grandes P, Manzoni OJ. Molecular components and functions of the endocannabinoid system in mouse prefrontal cortex. PLoS One. 2007;2:e709.

Lasseter HC, Xie X, Ramirez DR, Fuchs RA. Prefrontal cortical regulation of drug seeking in animal models of drug relapse. Curr Top Behav Neurosci. 2010;3:101-117. permission has been granted for this version to appear in e-Publications@Marquette. [Publisher] does not grant permission for this article to be further copied/distributed or hosted elsewhere without the express permission from [Publisher].] 
Leshner AI. Drug abuse and addiction treatment research. The next generation. Arch Gen Psychiatry. 1997;54:691-694.

Lin L, Grimm JW, Shaham Y, Hope BT. Molecular neuroadaptations in the accumbens and ventral tegmental area during the first 90 days of forced abstinence from cocaine self-administration in rats. J Neurochem. 2003;5:1604-1613.

Lindvall O, Bjorklund A, Divac I. Organization of catecholamine neurons projecting to the frontal cortex in the rat. Brain Res. $1978 ; 142: 1-24$.

Lisman J. Actin's actions in LTP-induced synapse growth. Neuron. $2003 ; 38: 361-362$.

London ED, Bonson KR, Ernst M, Grant S. Brain imaging studies of cocaine abuse: implications for medication development. Crit Rev Neurobiol. 1999;13:227-242.

Lu L, Grimm JW, Shaham Y, Hope BT. Molecular neuroadaptations in the accumbens and ventral tegmental area during the first 90 days of forced abstinence from cocaine self-administration in rats. J Neurochem. 2003;85:1604-1613.

Malinow R, Malenka RC. AMPA receptor trafficking and synaptic plasticity. Annu Rev Neurosci. 2002;25:103-126.

Mameli M, Bellone C, Brown MT, Lüscher C. Cocaine inverts rules for synaptic plasticity of glutamate transmission in the ventral tegmental area. Nat Neurosci. 2011;14:414-416.

Martin M, Chen BT, Hopf FW, Bowers MS, Bonci A. Cocaine selfadministration selectively abolishes LTD in the core of the nucleus accumbens. Nat Neurosci. 2006;9:868-869.

Martin-Fardon R, Baptista MA, Dayas CV, Weiss F. Dissociation of the effects of MTEP [3-[(2-methyl-1,3-thiazol-4-

$\mathrm{yl}$ )ethynyl]piperidine] on conditioned reinstatement and reinforcement: comparison between cocaine and a conventional reinforcer. ] Pharmacol Exp Ther. 2009;329:1084-1090. [

[Citation: Journal/Monograph Title, Vol. XX, No. X (yyyy): pg. XX-XX. DOI. This article is @ [Publisher's Name] and permission has been granted for this version to appear in e-Publications@Marquette. [Publisher] does not grant permission for this article to be further copied/distributed or hosted elsewhere without the express permission from [Publisher].] 
Matochik JA, London ED, Eldreth DA, Cadet JL, Bolla KI. Frontal cortical tissue composition in abstinent cocaine abusers: a magnetic resonance imaging study. Neuroimage. 2003;19:1095-1102.

McFarland K, Davidge SB, Lapish CC, Kalivas PW. Limbic and motor circuitry underlying footshock-induced reinstatement of cocaine-seeking behavior. J Neurosci. 2004;24:1551-1560.

McFarland K, Kalivas PW. The circuitry mediating cocaine-induced reinstatement of drug-seeking behavior. J Neurosci. $2001 ; 21: 8655-8663$.

McLaughlin J, See RE. Selective inactivation of the dorsomedial prefrontal cortex and the basolateral amygdala attenuates conditioned-cued reinstatement of extinguished cocaineseeking behavior in rats. Psychopharmacology (Berl) 2003; 168(1-2):57-65.

Mead AN, Zamanillo D, Becker N, Stephens DN. AMPA-receptor GluR1 subunits are involved in the control over behavior by cocainepaired cues. Neuropsychopharmacology. 2007;32:343-353.

Moussawi K, Pacchioni A, Moran M, Olive MF, Gass JT, Lavin A, Kalivas PW. N-Acetylcysteine reverses cocaine-induced metaplasticity. Nat Neurosci. 2009;12:182-189.

Moussawi K, Zhou W, Shen H, Reichel CM, See RE, Carr DB, Kalivas PW. Reversing cocaine-induced synaptic potentiation provides enduring protection from relapse. Proc Natl Acad Sci USA. 2011;108:385-390.

Novak M, Halbout B, O'Connor EC, Rodriguez Parkitna J, Su T, Chai M, Crombag HS, Bilbao A, Spanagel R, Stephens DN, Schütz G, Engblom D. Incentive learning underlying cocaine-seeking requires mGluR5 receptors located on dopamine D1 receptorexpressing neurons. J Neurosci. 2010;30:11973-11982.

O'Brien CP. A range of research-based pharmacotherapies for addiction. Science. 1997;278:66-70. 
O'Brien CP, McLellan AT. Myths about the treatment of addiction. Lancet. 1996;347:237-240.

Otani S, Auclair N, Desce JM, Roisin MP, Crépel F. Dopamine receptors and groups I and II mGluRs cooperate for long-term depression induction in rat prefrontal cortex through converging postsynaptic activation of MAP kinases. J Neurosci. 1999; 19:9788-9802.

Park WK, Bari AA, Jey AR, Anderson SM, Spealman RD, Rowlett JK, Pierce RC. Cocaine administered into the medial prefrontal cortex reinstates cocaine-seeking behavior by increasing AMPA receptor-mediated glutamate transmission in the nucleus accumbens. J Neurosci. 2002;22(7):2916-2925.

Peters J, Kalivas PW, Quirk GJ. Extinction circuits for fear and addiction overlap in prefrontal cortex. Learn Mem. 2009;16:279-288.

Peters J, LaLumiere RT, Kalivas PW. Infralimbic prefrontal cortex is responsible for inhibiting cocaine seeking in extinguished rats. J Neurosci. 2008;28:6046-6053.

Rebec GV, Sun W. Neuronal substrates of relapse to cocaine-seeking behavior: role of prefrontal cortex. J Exp Anal Behav. 2005;84:653-666.

Ribeiro FM, Ferreira LT, Paquet M, Cregan T, Ding Q, Gros R, Ferguson SS. Phosphorylation-independent regulation of metabotropic glutamate receptor 5 desensitization and internalization by $\mathrm{G}$ protein-coupled receptor kinase 2 in neurons. J Biol Chem. $2009 ; 284: 23444-23453$.

Robinson TE, Gorny G, Mitton E, Kolb B. Cocaine self-administration alters the morphology of dendrites and dendritic spines in the nucleus accumbens and neocortex. Synapse. 2001;39(3):257266.

Schaffhausen H, Cai Z, Hubalek F, Macek TA, Pohl J, Murphy TJ, et al. cAMP-dependent protein kinase inhibits mGluR2 coupling to $G$ - 
proteins by direct receptor phosphorylation. J Neurosci. $2000 ; 20: 5663-5670$.

Schnell E, Sizemore M, Karimzadegan S, Chen L, Bredt DS, Nicoll RA. Direct interactions between PSD95 and stargazing control synaptic AMPA receptor number. Proc Natl Acad Sci USA. 2002;99:13902-13907.

Self DW, Choi KH, Simmons D, Walker JR, Smagula CS. Extinction training regulates neuroadaptive responses to withdrawal from chronic cocaine self-administration. Learn Mem. 2004;11:648657.

Sesack SR, Deutch AY, Roth Rh, Bunney BS. Topographical organization of the efferent projections of the medial prefrontal cortex in the rat: an anterograde tract-tracing study with Phaseolus leucoagglutinin. J Comp Neurol. 1989;290:213-242.

Sesack SR, Pickel VM. Prefrontal cortical efferents in the rat synapse on unlabeled neuronal targets of catecholamine terminals in the nucleus accumbens spti and on dopamine neurons in the ventral tegmental area. J Comp Neurol. 1992;320:145-160.

Shen L, Liang F, Walensky LD, Huganir RL. Regulation of AMPA receptor GluR1 subunit surface expression by a 4. $1 \mathrm{~N}$-linked actin cytoskeletal association. J Neurosci. 2000;20:7932-7940.

Slipczuk L, Bekinschtein P, Katche C, Cammarota M, Izquierdo I, Medina JH. BDNF activates mTOR to regulate GluR1 expression required for memory formation. PLoS One. 2009;4(6):e6007.

Steketee JD. Neurotransmitter systems of the medial prefrontal cortex: potential role in sensitization to psychostimulants. Brain Res Rev. 2003;41:203-228.

Sun W, Akins CK, Mattingly AE, Rebec GV. Ionotropic glutamate receptors in the ventral tegmental area regulate cocaineseeking behavior in rats. Neuropsychopharmacology. 2005a;30:2073-2081.

[Citation: Journal/Monograph Title, Vol. XX, No. X (yyyy): pg. XX-XX. DOI. This article is @ [Publisher's Name] and permission has been granted for this version to appear in e-Publications@Marquette. [Publisher] does not grant permission for this article to be further copied/distributed or hosted elsewhere without the express permission from [Publisher].] 
Sun X, Zhao Y, Wolf ME. Dopamine receptor stimulation modulates AMPA receptor synaptic insertion in prefrontal cortex neurons. J Neurosci. 2005b;25:7342-7351.

Sutton MA, Schmidt EF, Choi KH, Schad CA, Whisler K, Simmons D, Karanian DA, Monteggia LM, Neve RL, Self DW. Extinctioninduced upregulation in AMPA receptors reduces cocaineseeking behaviour. Nature. 2003;421:70-75.

Tang W, Wesley M, Freeman WM, Liang B, Hemby SE. Alterations in ionotropic glutamate receptor subunits during binge cocaine self-administration and withdrawal in rats. J Neurochem. 2004;89:1021-1033.

Testa CM, Friberg IK, Weiss SW, Standaert DG. Immunohistochemical localization of metabotropic glutamate receptors mGluR1a and mGluR2/3 in the rat basal ganglia. J Comp Neurol. 1998;390:5-19.

Thierry AM, Blanc G, Sobel A, Stinus L, Glowinski J. Dopaminergic terminals in the rat Cortex. Science. 1973;182:499-501.

Thomas MJ, Kalivas PW, Shaham Y. Neuroplasticity in the mesolimbic dopamine system and cocaine addiction. British Journal of Pharmacology. 2008;154:327-342.

Toda S, Alguacil LF, Kalivas PW. Repeated cocaine administration changes the function and subcellular distribution of adenosine A1 receptor in the rat nucleus accumbens. J Neurochem. 2003;87:1478-1484.

Toda S, Shen HW, Peters J, Cagle S, Kalivas PW. Cocaine increases actin cycling: effects in the reinstatement model of drug seeking. J Neurosci. 2006;26:1579-1587.

Tu JC, Xiao B, Naisbitt S, Yuan JP, Petralia RS, Brakeman P, et al. Coupling of mGluR/ Homer and PSD-95 complexes by the shank family of postsynaptic density proteins. Neuron. $1999 ; 23: 583-592$.

[Citation: Journal/Monograph Title, Vol. XX, No. X (yyyy): pg. XX-XX. DOI. This article is @ [Publisher's Name] and permission has been granted for this version to appear in e-Publications@Marquette. [Publisher] does not grant permission for this article to be further copied/distributed or hosted elsewhere without the express permission from [Publisher].] 
Van den Oever MC, Goriounova NA, Li KW, Van der Schors RC, Binnekade R, Schoffelmeer AN, Mansvelder HD, Smit AB, Spijker S, De Vries TJ. Prefrontal cortex AMPA receptor plasticity is crucial for cue-induced relapse to heroin-seeking. Nat Neurosci. 2008;11:1053-1058.

Van den Oever MC, Spijker S, Smit AB, De Vries TJ. Prefrontal cortex plasticity mechanisms in drug seeking and relapse. Neurosci Biobehav Rev. 2010;35:276-284.

Volkow ND, Fowler JS. Addiction, a disease of compulsion and drive: involvement of the orbitofrontal cortex. Cereb Cortex. $2000 ; 10: 318-325$.

Whitlock JR, Heynen AJ, Shuler MG, Bear MF. Learning induces longterm potentiation in the hippocampus. Science. 2006;313:1093-1097.

Wise RA. Ventral tegmental glutamate: a role in stress-, cue-, and cocaine-induced reinstatement of cocaine-seeking. Neuropharmacology. 2009;56(Suppl 1):174-176.

Wyszynski M, Kharazia V, Shanghvi R, Rao A, Beggs AH, Craig AM, et al. Differential regional expression and ultrastructural localization of a-actinin-2, a putative NMDA receptor anchoring protein, in rat brain. J Neurosci. 1998;18:1383-1392.

Xiao B, Tu JC, Petralia RS, Yuan JP, Doan A, Breder CD, et al. Homer regulates the association of group 1 metabotropic glutamate receptors with multivalent complexes of homer-related synaptic proteins. Neuron. 1998;21:707-716.

Zhang Y, Venkitaramani DV, Gladding CM, Zhang Y, Kurup P, Molnar E, Collingridge $\mathrm{GL}$, Lombroso PJ. The tyrosine phosphatase STEP mediates AMPA receptor endocytosis after metabotropic glutamate receptor stimulation. J Neurosci. 2008;28:1056110566. 
NOT THE PUBLISHED VERSION; this is the author's final, peer-reviewed manuscript. The published version may be accessed by following the link in the citation at the bottom of the page.

\section{Supplementary Material}

\section{1}

http://www.ncbi.nlm.nih.gov/pmc/articles/PMC4000163/bin/NIHMS32 0629-supplement-01.pdf (98K, pdf)

\section{Subjects}

Seventy-five adult male Sprague-Dawley rats (Harlan Laboratories, Inc., St. Louis, MO), approximately 90 days old (325 g) were used for the study. Rats were housed individually in a temperature- and humidity-controlled, AAALACaccredited animal facility under a $12 \mathrm{~h} / 12 \mathrm{~h}$ reversed light/dark cycle (lights on at 6:00 pm) and had access to food at all times, except when in the experimental chambers. Water was available at all times during the study, including in the experimental chambers. All procedures were carried out in accordance with the Guide for the Care and Use of Laboratory Animals as adopted and promulgated by the NIH.

\section{Catheterization surgery}

Rats were implanted with chronic indwelling catheters under ketamine $\mathrm{HCl}$ $(100 \mathrm{mg} / \mathrm{kg}$, ip, Fort Dodge Animal Health, Fort Dodge, IA) and xylazine (2 $\mathrm{mg} / \mathrm{kg}$, ip, Lloyd Laboratories, Shenandoah, IA) anesthesia. A silicon tubing catheter (Silastic $®$; Dow Corning Co., Midland, MI; 0.64 mm i.d.; $1.19 \mathrm{~mm}$ o.d.) was inserted into the right posterior facial vein and down into the jugular vein so that it terminated at the right atrium. The catheter was sutured to the vein and continued subcutaneously to the animal's back where it exited $2 \mathrm{~cm}$ posterior to the scapula via a back-mounted 22-gauge guide cannula (Plastics One Inc., Roanoke, VA) attached using dental acrylic to a piece of polypropylene monofilament surgical mesh (Atrium Medical, Co., Hudson, $\mathrm{NH})$ to permit connection of a polyethylene delivery line $(0.58 \mathrm{~mm}$ i.d. x $1.27 \mathrm{~mm}$ o.d.; Plastics One Inc., Roanoke, VA) encased in a stainless steel spring leash (Plastics One). The delivery line was connected to a 30-ml syringe in a motor-driven pump (Razel, Stamford, CT) via a leakproof fluid swivel (Instech Lab. Inc., Plymouth Meeting, PA) suspended above the chamber to allow drug delivery. The swivel and leash assembly was counterbalanced to permit relatively unrestrained movement. Rats were allowed to recover for at least three days prior to SA testing during which time they were provided acetaminophen $(480 \mathrm{mg} / \mathrm{L})$ in their drinking water. After implantation, rats were injected with a sterile cefazolin antibiotic solution (15 mg, iv; West-Ward Pharmaceutical Co., Eatontown, NJ) each day. Catheters were filled daily with a heparin solution (83 i.u./ml) and capped whenever the leash/delivery line assembly was disconnected.

\section{Self-administration apparatus}

[Citation: Journal/Monograph Title, Vol. XX, No. X (yyyy): pg. XX-XX. DOI. This article is @ [Publisher's Name] and permission has been granted for this version to appear in e-Publications@Marquette. [Publisher] does not grant permission for this article to be further copied/distributed or hosted elsewhere without the express permission from [Publisher].] 
NOT THE PUBLISHED VERSION; this is the author's final, peer-reviewed manuscript. The published version may be accessed by following the link in the citation at the bottom of the page.

Twenty operant conditioning chambers encased in sound attenuating cubicles (Med-Associates Inc., St Albans, VT) were used. One retractable lever and stimulus light were mounted on the front wall of the chamber. A second lever and light were located on the back wall. Exhaust fans in the cabinets provided ventilation and white noise to mask extraneous sound.

\section{Self-administration training and testing}

Following recovery from surgery, rats were trained to self-administer cocaine $(1.0 \mathrm{mg} / \mathrm{kg} / \mathrm{inf}$, iv, NIDA, Bethesda, MD) or provided access to saline solution by pressing a lever under a FR1 schedule during daily 2-h sessions, within which the active (i.e., front) lever was extended into the chamber and the corresponding stimulus light was illuminated. Pressing the lever resulted in an iv infusion of drug or saline solution $(200 \mu$ l over $5 \mathrm{~s}$ ) followed by a 25 -s timeout period during which the stimulus light was extinguished but the lever remained extended. Responding on a second, inactive (i.e., back) lever was recorded but had no programmed consequences. Once a stable response pattern was observed during the 2 -h sessions (total responding $<10 \%$ variation from the mean over 3 consecutive sessions), rats were ready for SA testing. During SA testing, the duration of daily cocaine/saline access was increased to $6 \mathrm{hrs}$. Rats were permitted to self-administer under these conditions for 14 days prior to exposure to extinction (Ext), homecage (Home), or SA box (Box) conditions after self-administration period.

\section{Withdrawal conditions following cocaine self-administration (Post-} SA)

Cocaine and saline SA rats were exposed to one of three conditions during post-SA (Extinction, Home, Box). For Extinction rats, the cocaine solution was replaced with saline for ten consecutive 6 -h extinction sessions conducted over a 12-14 day period. Aside from saline rather than cocaine availability, these sessions were otherwise identical to the SA sessions. Saline Extinction rats continued to have access to saline during these ten sessions. For the other two conditions rats did not undergo extinction during the 12-14 day post-SA period, but rather remained in their home cages (Home rats) or were introduced into the SA boxes for six hours each day with the levers retracted and stimulus lights extinguished (Box rats).

\section{Cocaine-seeking behavior}

Cocaine-seeking behavior was recorded in six Home rats, eight Box rats, and ten Extinction rats. For the Home and Box rats, cocaine seeking was measured during a 6 -h session within which lever pressing resulted in saline infusions conducted after a 12-14 day post-SA period during which they remained in their home cages (Home rats) or were introduced into the SA boxes for six hrs each day with the levers retracted and stimulus lights

[Citation: Journal/Monograph Title, Vol. XX, No. X (yyyy): pg. XX-XX. DOI. This article is @ [Publisher's Name] and permission has been granted for this version to appear in e-Publications@Marquette. [Publisher] does not grant permission for this article to be further copied/distributed or hosted elsewhere without the express permission from [Publisher].] 
NOT THE PUBLISHED VERSION; this is the author's final, peer-reviewed manuscript. The published version may be accessed by following the link in the citation at the bottom of the page.

extinguished (Box rats). For Extinction rats, data collected during the final 6-h extinction session (i.e., extinction day 10 ) were used for comparison. The Home and Box rats in which cocaine seeking was measured were not used for protein determination.

\section{Anatomical dissection and biochemical subcellular fractionation}

At the end of the post-SA period, Home, Box, and Extinction rats were decapitated and brains quickly removed from the skull and placed in ice-cold saline for one minute. The tissue was blocked and coronal slices containing areas of interest were cut using a rat brain matrix (ASI, Warren, MI). The medial prefrontal cortex (mPFC) was blocked between plates 6 and 11 (Bregma 5.16-3.00 mm) (paxinos and Watson, 2005). The dorsal and ventral PFC border was set at the middle of prelimbic cortex based on previous anatomical and functional studies (Heidbreder and Groenewegen, 2003) and was hand dissected. The ventral tegmental area was blocked between plates 77-85 (Bregma -5.28-6.24 mm) and was hand dissected. All tissue samples were immediately frozen on dry ice and stored at $-80^{\circ} \mathrm{C}$. The membrane preparation and biochemical fractionation were based on methods by Dunah and Standaert (2001) and Toda et al, (2003). A schematic of the membrane purification procedure, adopted from Dunah and Standaert (2001), is presented in Supplementary figure 1. The tissue was homogenized in ice-cold TEVP buffer containing (in mM) 10 Tris- $\mathrm{HCl}, \mathrm{pH} 7.4,5 \mathrm{NaF}, 1 \mathrm{Na}$ VO4, 1 EDTA, 1 EGTA, 320 sucrose, using a Dounce glass homogenizer. An aliquot of the whole tissue Dounce homogenate ( $\mathrm{H}$ fraction) was collected, and the remainder was centrifuged at $1000 \mathrm{~g}$ to remove nuclei and large debris (P1). The supernatant (S1) was centrifuged at $10,000 \mathrm{~g}$ to obtain a crude synaptosomal fraction (P2) and subsequently was lysed hypo-osmotically for $30 \mathrm{~min}$ at $4^{\circ} \mathrm{C}$ and centrifuged at $25,000 \mathrm{~g}$ to pellet a synaptosomal membrane fraction (LP1), which is enriched in postsynaptic density. All centrifugations were carried out at $4^{\circ} \mathrm{C}$. LP1 pellets were resuspended in TEVP. The $\mathrm{H}$ and LP1 fractions were solubilized with the addition of SDS to $1 \%(\mathrm{v} / \mathrm{v})$ and used for protein concentration measurement and Western Blot Analysis. All fractions were saved and stored at $-80^{\circ} \mathrm{C}$.

\section{Western blot analysis}

Two independent protein analyses were performed. In the first analysis, all saline-treated animals ( $n=10$ per post-SA treatment group) were compared across post-SA conditions (i.e., 8 saline samples from Post-SA treatment conditions (2-3 samples from each Post-SA treatment) were loaded onto each gel and the mean percent changes compared to Home samples on the same gel were determined). This was done to identify any effects of post-SA conditions that were independent of cocaine exposure. The second analysis compared cocaine-treated animals $(n=10)$ to their corresponding saline

[Citation: Journal/Monograph Title, Vol. XX, No. X (yyyy): pg. XX-XX. DOI. This article is @ [Publisher's Name] and permission has been granted for this version to appear in e-Publications@Marquette. [Publisher] does not grant permission for this article to be further copied/distributed or hosted elsewhere without the express permission from [Publisher].] 
control group $(n=10)$ for each post-SA treatment (i.e., 3-4 samples each from saline and cocaine treated animals were loaded onto each gel and the mean percent change resulting from cocaine self-administration was determined based on values for saline samples on the same gel). Due to the large number of samples, each of the three comparisons (10 saline and 10 cocaine for each post-SA treatment) was done separately. Protein concentration was determined by the Lowry based DC protein assay (Bio-Rad, Hercules, CA). Protein samples were resolved by SDS-PAGE according to the method described by Ghasemzadeh et al., 2003. Briefly, proteins were transferred from the gel to a polyvinyldine fluoride (PVDF) membrane using a semi-dry transfer apparatus (Bio-Rad, Hercules, CA). Membranes were blocked for 2 hour at room temperature (Tris-buffered saline containing 3\% non-fat dry milk) and incubated with commercially obtained primary antibody in antibody buffer (blocking buffer containing Tween-20, $50 \mu \mathrm{l} / 100 \mathrm{ml}$ ) overnight at $4{ }^{\circ} \mathrm{C}$, washed with antibody buffer, and incubated with HRP-conjugated secondary antibody for 90 minutes at room temperature. Membranes were washed and immunolabeling was visualized with enhanced chemiluminescence (ECL method). Chemiluminescent images were captured using a Kodak Image Station 4000MM. Band density was measured using Kodak Molecular Imaging Software v4.0. Commercially available antibodies were used to probe for the presence of proteins. The following primary antibodies were used in this study: mouse NMDAR1 (Millipore, Cat. \# 05-432, 1:3000 dilution), rabbit GluR1 (Millipore, Cat. \# 07-660, 1:10,000 dilution), rabbit mGluR5 (Millipore, Cat. \# 06-451, 1:10,000 dilution), mouse PSD95 (Antibodies Inc., Cat. \# 75028, 1:10,000 dilution), mouse PICK1 (Antibodies Inc., Cat. \# 75-040, 1:3000 dilution), rabbit Homer1b/c (Santa Cruz Biotech, Cat. \# sc-20807, 1:3000 dilution), goat Actin (Santa Cruz Biotech, Cat. \# sc-1615, 1:10,000). The following HRP-conjugated secondary antibodies were used: goat antirabbit IgG (Millipore, Cat. \# 12-348, 1:20,000 dilution), goat anti-mouse IgG (Millipore, Cat. \# 12-349, 1:20,000 dilution).

\section{Statistics}

The self-administration data (infusions/session) were evaluated using twoway ANOVA with repeated measures over sessions. Responding on test day (infusions/session) was compared using one-way ANOVA comparing the three post-SA treatment groups. In both cases, differences between groups were determined using post hoc Fisher's PLSD. For analysis of cocaine selfadministration induced alterations in protein levels under each of the three post-SA conditions, immunoreactivity of protein samples from cocaine and saline rats was normalized as percent change relative to the respective mean saline control values for samples on the same gel. Normalized saline and cocaine values were then compared separately for each post-SA condition using Student's t-tests. To permit comparison of cocaine-induced changes

[Citation: Journal/Monograph Title, Vol. XX, No. X (yyyy): pg. XX-XX. DOI. This article is @ [Publisher's Name] and permission has been granted for this version to appear in e-Publications@Marquette. [Publisher] does not grant permission for this article to be further copied/distributed or hosted elsewhere without the express permission from [Publisher].] 
NOT THE PUBLISHED VERSION; this is the author's final, peer-reviewed manuscript. The published version may be accessed by following the link in the citation at the bottom of the page.

across post-SA treatment conditions, saline self-administration effects on protein levels determined from a separate protein analysis were initially compared across post-SA conditions using one-way ANOVA followed by the Fisher's PLSD test to identify any effects of post-SA conditions that were independent of cocaine exposure. For this analysis saline self-administration induced protein alterations under each of the post-SA conditions were normalized as percent change relative to the respective mean Home sample saline values determined from the same gel. In cases where there were no differences following saline exposure across post-SA conditions, percent changes in protein following cocaine self-administration were compared across post-SA conditions using one-way ANOVA, followed by post-hoc testing using the Fisher's PLSD test.

Statistical significance was set at $p<0.05$. 
NOT THE PUBLISHED VERSION; this is the author's final, peer-reviewed manuscript. The published version may be accessed by following the link in the citation at the bottom of the page.

02

http://www.ncbi.nlm.nih.gov/pmc/articles/PMC4000163/bin/NIHMS32

0629-supplement-02.doc (2.9M, doc)

A.

$+3.00$
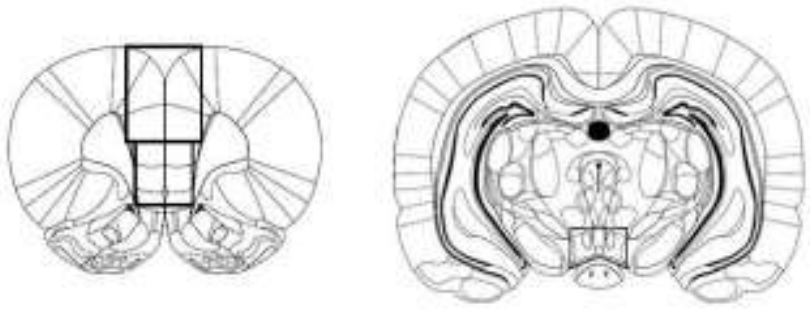

Homogenized Tissue

B.

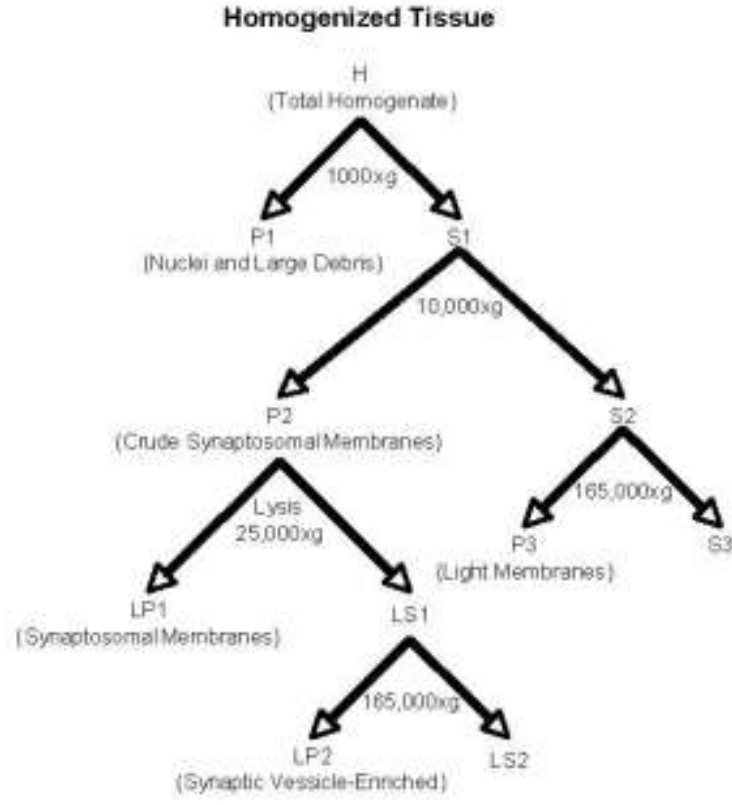

C.

Synaptophysin

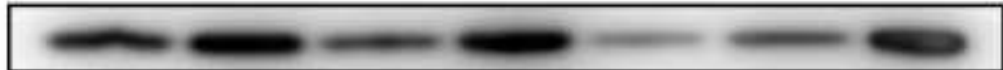

GM 130

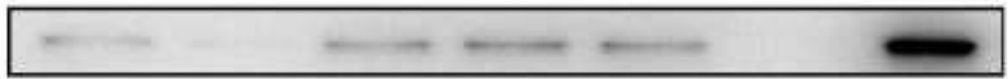

Calnexin

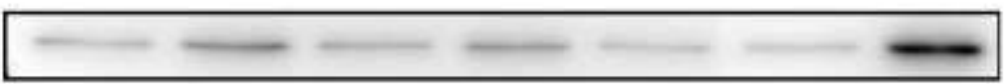

PSD-95

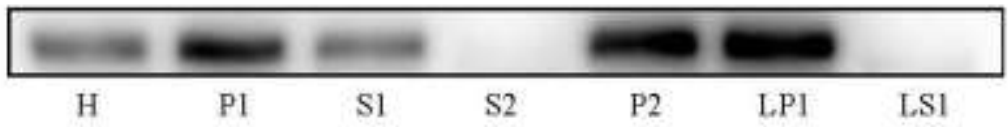

[Citation: Journal/Monograph Title, Vol. XX, No. X (yyyy): pg. XX-XX. DOI. This article is (C [Publisher's Name] and permission has been granted for this version to appear in e-Publications@Marquette. [Publisher] does not grant permission for this article to be further copied/distributed or hosted elsewhere without the express permission from [Publisher].] 
03

http://www.ncbi.nlm.nih.gov/pmc/articles/PMC4000163/bin/NIHMS32

0629-supplement-03.tif (1.2M, tif)

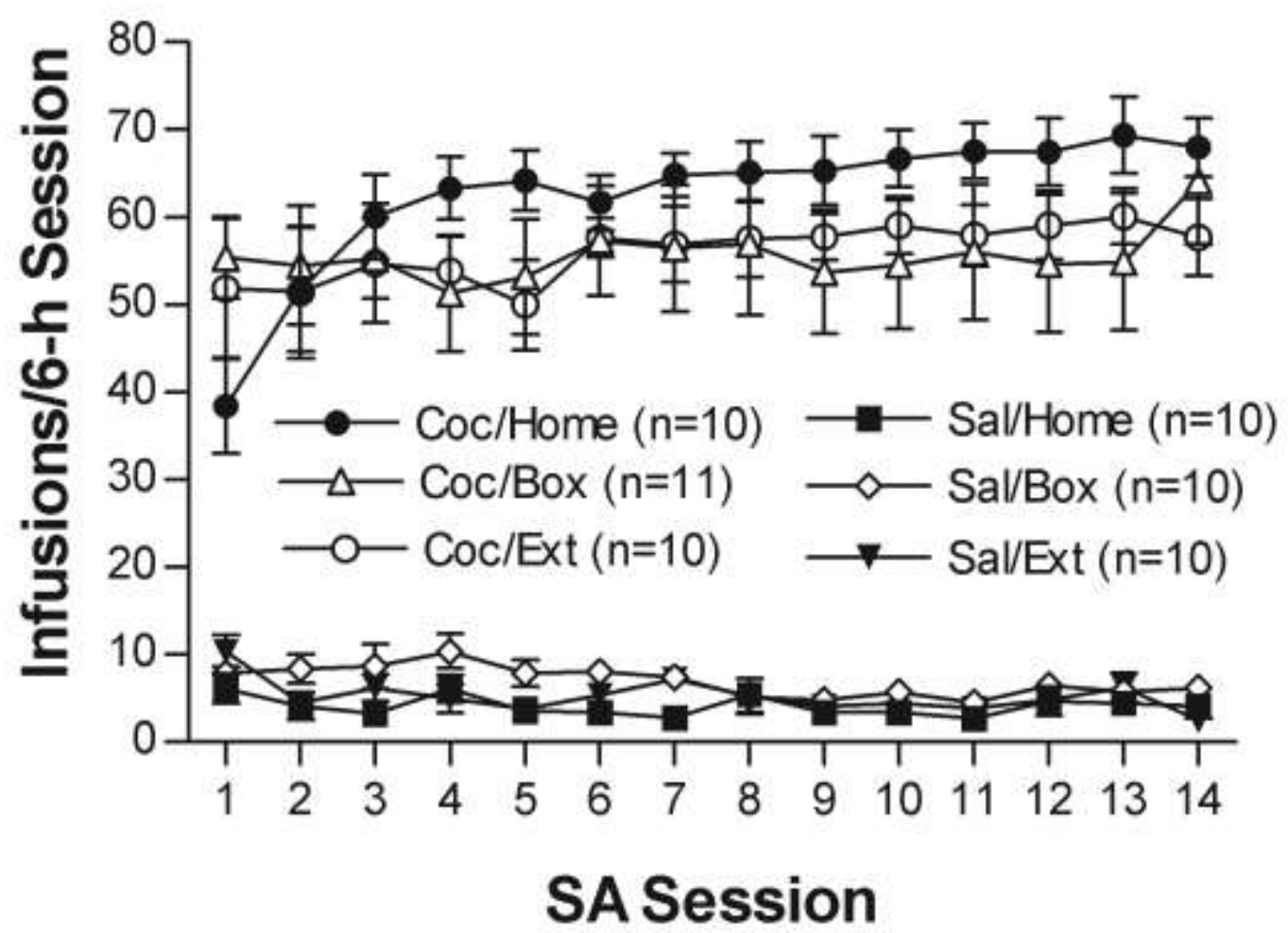

[Citation: Journal/Monograph Title, Vol. XX, No. X (yyyy): pg. XX-XX. DOI. This article is @ [Publisher's Name] and permission has been granted for this version to appear in e-Publications@Marquette. [Publisher] does not grant permission for this article to be further copied/distributed or hosted elsewhere without the express permission from [Publisher].] 
NOT THE PUBLISHED VERSION; this is the author's final, peer-reviewed manuscript. The published version may be accessed by following the link in the citation at the bottom of the page.

04

http://www.ncbi.nlm.nih.gov/pmc/articles/PMC4000163/bin/NIHMS32

0629-supplement-04.tif (983K, tif)

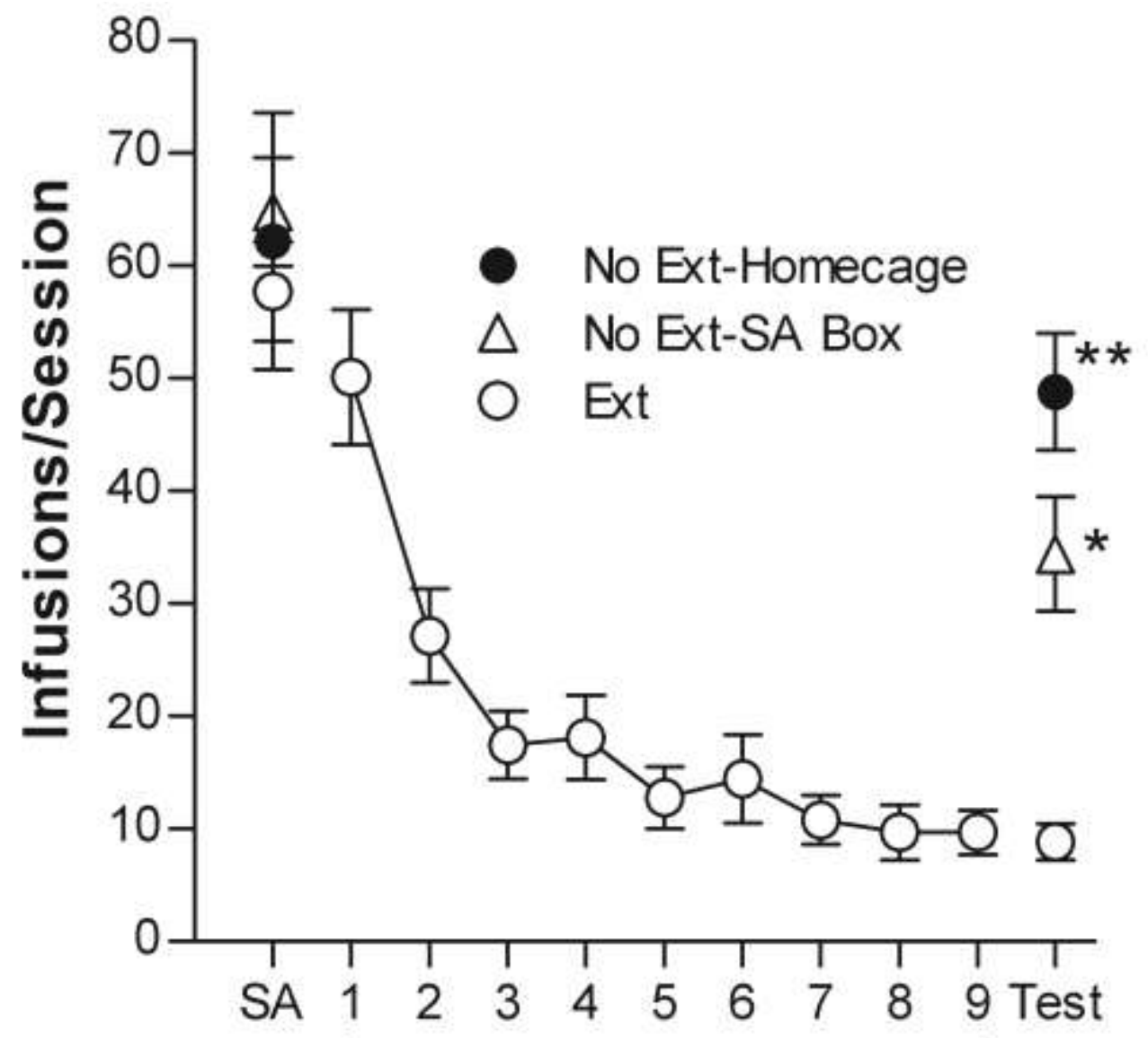

Extinction

[Citation: Journal/Monograph Title, Vol. XX, No. X (yyyy): pg. XX-XX. DOI. This article is @ [Publisher's Name] and permission has been granted for this version to appear in e-Publications@Marquette. [Publisher] does not grant permission for this article to be further copied/distributed or hosted elsewhere without the express permission from [Publisher].] 
NOT THE PUBLISHED VERSION; this is the author's final, peer-reviewed manuscript. The published version may be accessed by following the link in the citation at the bottom of the page.

05

http://www.ncbi.nIm.nih.gov/pmc/articles/PMC4000163/bin/NIHMS32

0629-supplement-05.ppt (119k, ppt)
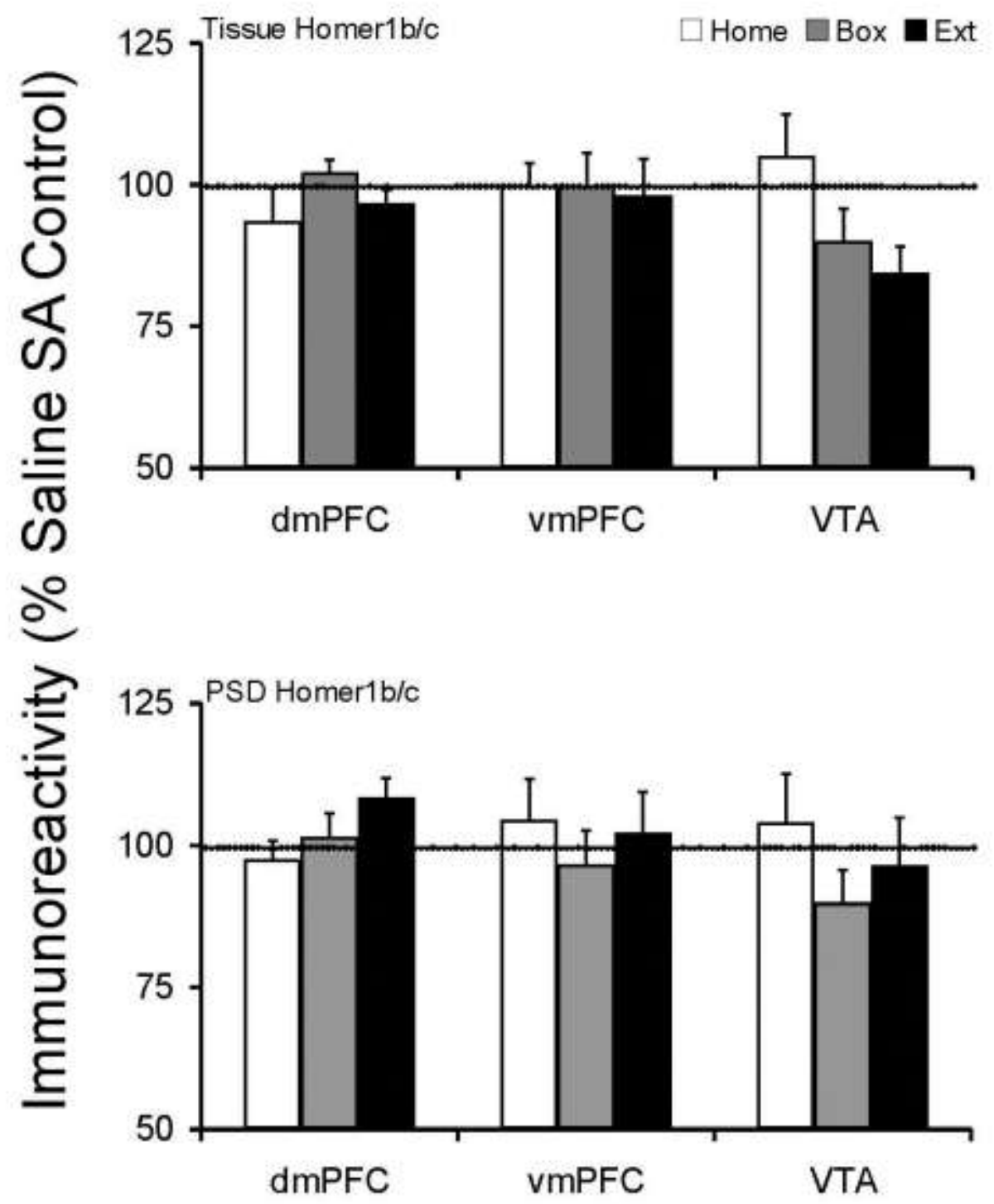

[Citation: Journal/Monograph Title, Vol. XX, No. X (yyyy): pg. XX-XX. DOI. This article is @ [Publisher's Name] and permission has been granted for this version to appear in e-Publications@Marquette. [Publisher] does not grant permission for this article to be further copied/distributed or hosted elsewhere without the express permission from [Publisher].] 
NOT THE PUBLISHED VERSION; this is the author's final, peer-reviewed manuscript. The published version may be accessed by following the link in the citation at the bottom of the page.

06

http://www.ncbi.nIm.nih.gov/pmc/articles/PMC4000163/bin/NIHMS32 0629-supplement-06.ppt (119k, ppt)
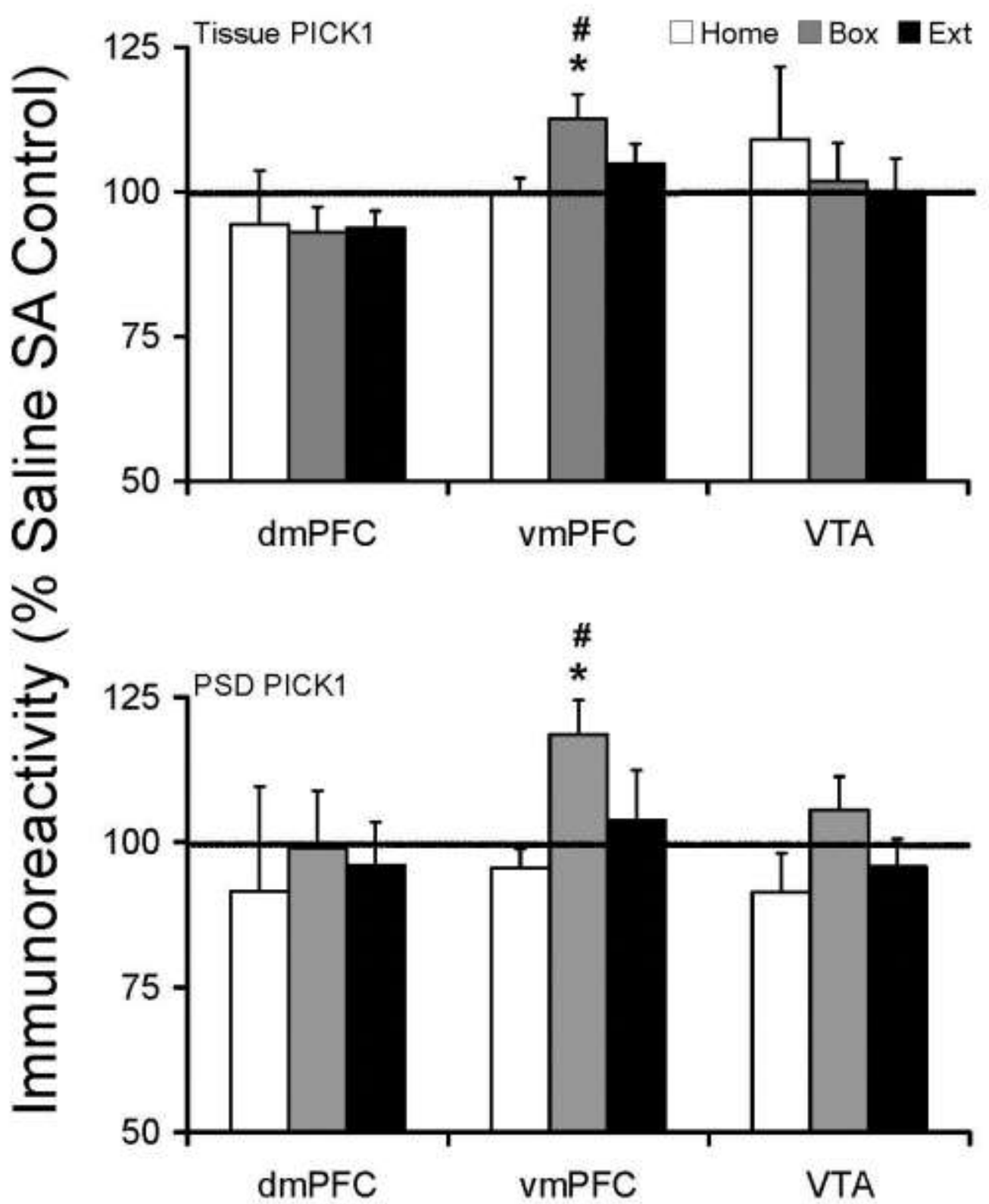

[Citation: Journal/Monograph Title, Vol. XX, No. X (yyyy): pg. XX-XX. DOI. This article is @ [Publisher's Name] and permission has been granted for this version to appear in e-Publications@Marquette. [Publisher] does not grant permission for this article to be further copied/distributed or hosted elsewhere without the express permission from [Publisher].] 
NOT THE PUBLISHED VERSION; this is the author's final, peer-reviewed manuscript. The published version may be accessed by following the link in the citation at the bottom of the page.

\section{7}

http://www.ncbi.nlm.nih.gov/pmc/articles/PMC4000163/bin/NIHMS32 0629-supplement-07.ppt (126K, ppt)

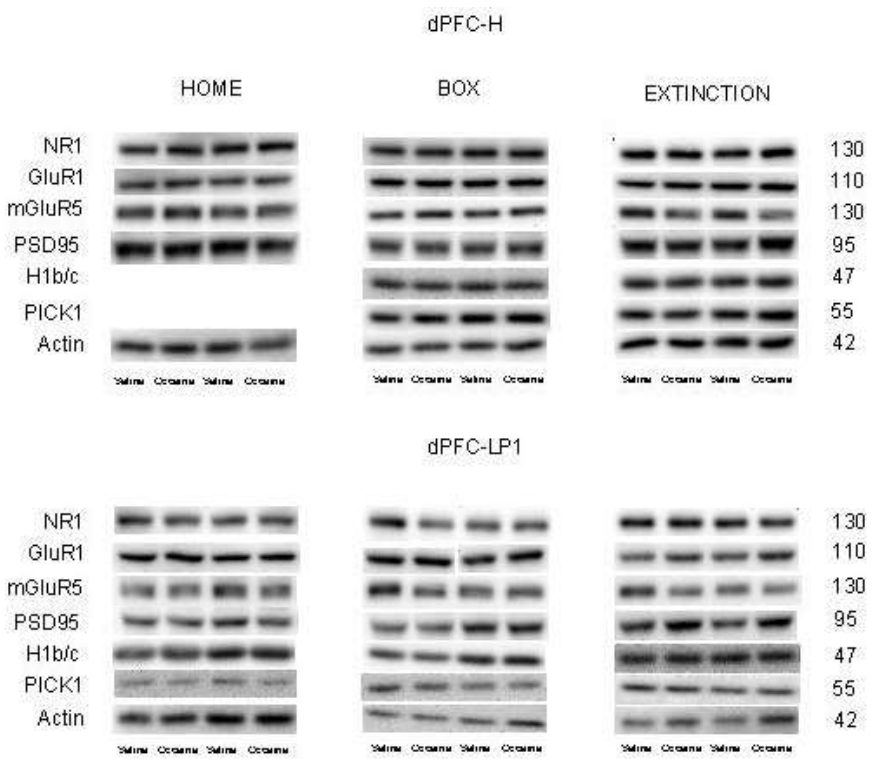

[Citation: Journal/Monograph Title, Vol. XX, No. X (yyyy): pg. XX-XX. DOI. This article is @ [Publisher's Name] and permission has been granted for this version to appear in e-Publications@Marquette. [Publisher] does not grant permission for this article to be further copied/distributed or hosted elsewhere without the express permission from [Publisher].] 
NOT THE PUBLISHED VERSION; this is the author's final, peer-reviewed manuscript. The published version may be accessed by following the link in the citation at the bottom of the page.

\section{8}

http://www.ncbi.nlm.nih.gov/pmc/articles/PMC4000163/bin/NIHMS32

0629-supplement-08.ppt (135k, ppt)
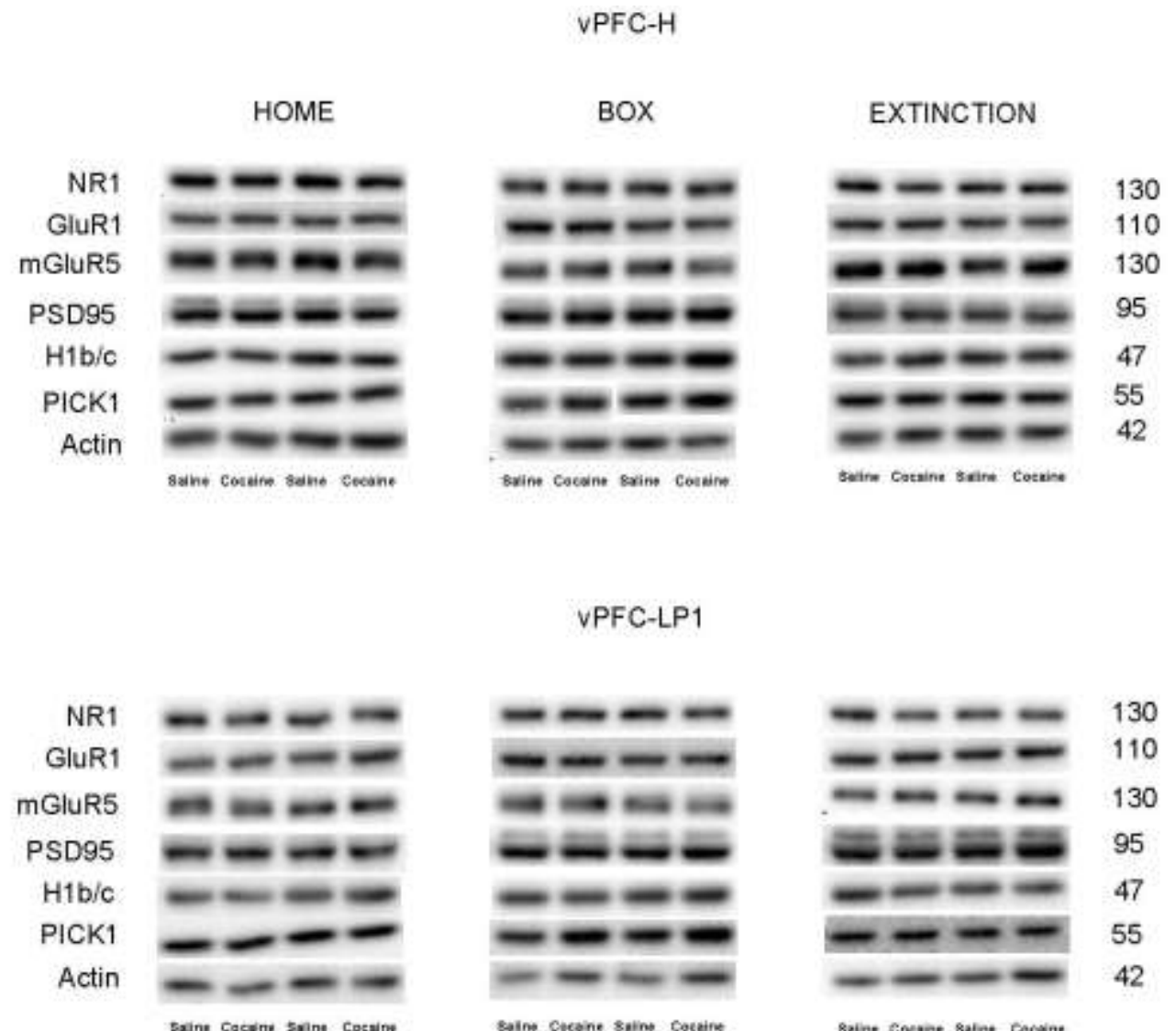

130 
NOT THE PUBLISHED VERSION; this is the author's final, peer-reviewed manuscript. The published version may be accessed by following the link in the citation at the bottom of the page.

\section{9}

http://www.ncbi.nlm.nih.gov/pmc/articles/PMC4000163/bin/NIHMS32

0629-supplement-09.ppt (170k, ppt)

$$
\text { VTA - H }
$$

HOME

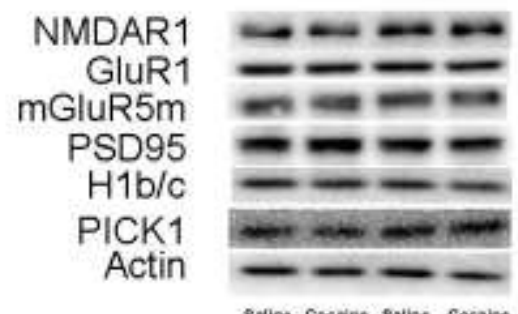

Suline Cocaine Salibe Cocaibs

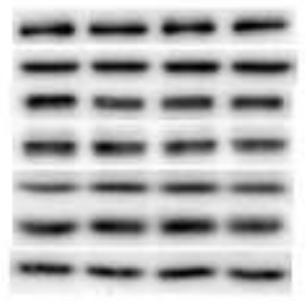

Saine Cocans saline Cecaint

$$
\text { VTA - LP1 }
$$

\section{NR1 \\ GluR1 \\ mGluR5m \\ PSD95 \\ $\mathrm{H} 1 \mathrm{~b} / \mathrm{c}$ \\ PICK1 \\ Actin}

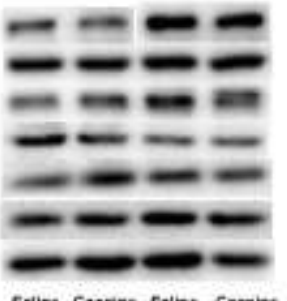

Saline Cecaine saine Cacaine

\section{BOX}

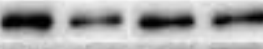

20

$=0$
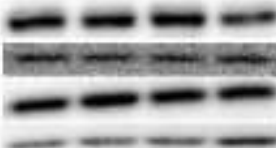

Sacine cotans seline Cecaine

\section{EXTINCTION}

BOX
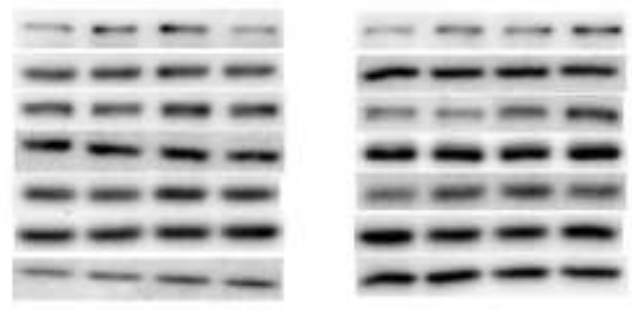
NOT THE PUBLISHED VERSION; this is the author's final, peer-reviewed manuscript. The published version may be accessed by following the link in the citation at the bottom of the page.

10

http://www.ncbi.nIm.nih.gov/pmc/articles/PMC4000163/bin/NIHMS32

0629-supplement-10.pdf (65K, pdf)

\section{Supplementary Figure Legends}

Figure 1S. Subcellular fractionation analysis. Panel A shows the dissection of the medial prefrontal cortex (dorsal and ventral) and ventral tegmental area. The numbers on the coronal brain section represent distance from Bregma. Panel B shows a schematic of the subcellular fractionation procedure, as described in Material and Methods (adopted from Dunah and Standaert, 2001). The H and LP1 fractions were used for western blot analysis. Panel C shows representative immunoblots from nucleus accumbens tissue characterizing the content of each fraction. The membrane was probed with markers for presynaptic vesicles (synaptophysin), Golgi apparatus (GM 130), endoplasmic reticulum (calnexin), and postsynaptic density (PSD 95). The H fraction contains all of the probed subcellular compartment markers while the LP1 fraction is highly enriched in PSD 95, contains lesser amounts of synaptophysin, trace amounts of calnexin, and is devoid of GM 130.

Figure 2S. Cocaine and saline self-administration in Home, Box and Extinction rats used for protein analysis. Data represent the number of infusions acquired by rats subsequently assigned to the Home, Box, and Extinction post-SA conditions across the 14-day test period during which cocaine (Coc) or saline (Sal) infusions were available during daily 6-h selfadministration sessions. No differences in saline or cocaine self-administration were observed between rats assigned to the various post-SA conditions.

Figure 3S. Effects of post-SA conditions on cocaine-seeking behavior. Data represent the number of infusions acquired during the 6-h sessions on the final day of self-administration (SA), across a 9-day post-SA period and during a test session conducted after post-SA period in rats allowed to remain in the home cage with no further treatment (Home), rats exposed daily to the self-administration chambers in absence of exposed levers or other cocaineassociated cues (Box) and rats engaged in daily extinction training (Extinction). Cocaine-seeking behavior was significantly reduced in Extinction rats compared to rats exposed to Home or Box conditions ( $* * p<0.0001$ vs. Home and Box) and was significantly lower in rats exposed to Box conditions compared to rats exposed to Home conditions $(* p=0.026)$.

Figure 4S. Tissue and postsynaptic density (synaptosomal membrane fraction) levels of Homer1b/c protein after cocaine self-administration and Home, Box, and Extinction treatments. See Figure 1 legend for details. The

[Citation: Journal/Monograph Title, Vol. XX, No. X (yyyy): pg. XX-XX. DOI. This article is @ [Publisher's Name] and permission has been granted for this version to appear in e-Publications@Marquette. [Publisher] does not grant permission for this article to be further copied/distributed or hosted elsewhere without the express permission from [Publisher].] 
NOT THE PUBLISHED VERSION; this is the author's final, peer-reviewed manuscript. The published version may be accessed by following the link in the citation at the bottom of the page.

tissue and PSD levels of Homer1b/c protein were not changed following any post-SA treatment.

Figure 5S. Tissue and postsynaptic density (synaptosomal membrane fraction) levels of PICK1 protein after cocaine self-administration and Home, Box, and Extinction treatments. See Figure 1 legend for details. The tissue and PSD levels of PICK1 protein were significantly increased in Box group in vmPFC. Comparing cocaine self-administration groups across post-SA conditions, there were significant differences in tissue and PSD levels of PICK1 protein between Box and Home groups. $* \mathrm{p}<0.05$ compared to respective saline control. \#p<0.05 compared to cocaine Home group.

Figure 6S. Representative protein bands from dmPFC of saline and cocaine self-administration animals following post-SA treatments. See Methods for description of the experimental conditions. The top panel shows results from the tissue protein analysis ( $\mathrm{H}$ fraction). The bottom panel shows results from the synaptosomal membrane fraction (postsynaptic density) protein analysis (LP1 fraction).

Figure 7S. Representative protein bands from vmPFC of saline and cocaine self-administration animals following post-SA treatments. See Methods for description of the experimental conditions. The top panel shows results from the tissue protein analysis ( $\mathrm{H}$ fraction). The bottom panel shows results from the synaptosomal membrane fraction (postsynaptic density) protein analysis (LP1 fraction).

Figure 8S. Representative protein bands from VTA of saline and cocaine selfadministration animals following post-SA treatments. See Methods for description of the experimental conditions. The top panel shows results from the tissue protein analysis ( $\mathrm{H}$ fraction). The bottom panel shows results from the synaptosomal membrane fraction (postsynaptic density) protein analysis (LP1 fraction).

\section{Anatomical dissection and biochemical subcellular fractionation} At the end of the post-SA period, Home, Box, and Extinction rats were decapitated and brains quickly removed from the skull and placed in ice-cold saline for one minute. The tissue was blocked and coronal slices containing areas of interest were cut using a rat brain matrix (ASI, Warren, MI). The medial prefrontal cortex (mPFC) was blocked between plates 6 and 11 (Bregma 5.16-3.00 mm) (paxinos and Watson, 2005). The dorsal and ventral PFC border was set at the middle of prelimbic cortex based on previous anatomical and functional studies (Heidbreder and Groenewegen, 2003) and was hand dissected. The ventral tegmental area was blocked between plates

[Citation: Journal/Monograph Title, Vol. XX, No. X (yyyy): pg. XX-XX. DOI. This article is (C) [Publisher's Name] and permission has been granted for this version to appear in e-Publications@Marquette. [Publisher] does not grant permission for this article to be further copied/distributed or hosted elsewhere without the express permission from [Publisher].] 
77-85 (Bregma -5.28-6.24 mm) and was hand dissected. All tissue samples were immediately frozen on dry ice and stored at $-80^{\circ} \mathrm{C}$. The membrane preparation and biochemical fractionation were based on methods by Dunah and Standaert (2001) and Toda et al, (2003). A schematic of the membrane purification procedure, adopted from Dunah and Standaert (2001), is presented in Supplementary figure 1 . The tissue was homogenized in ice-cold TEVP buffer containing (in mM) 10 Tris- $\mathrm{HCl}, \mathrm{pH} 7.4,5 \mathrm{NaF}, 1 \mathrm{Na}$ VO4, 1 EDTA, 1 EGTA, 320 sucrose, using a Dounce glass homogenizer. An aliquot of the whole tissue Dounce homogenate ( $H$ fraction) was collected, and the remainder was centrifuged at $1000 \mathrm{~g}$ to remove nuclei and large debris (P1). The supernatant (S1) was centrifuged at $10,000 \mathrm{~g}$ to obtain a crude synaptosomal fraction (P2) and subsequently was lysed hypo-osmotically for $30 \mathrm{~min}$ at $4^{\circ} \mathrm{C}$ and centrifuged at $25,000 \mathrm{~g}$ to pellet a synaptosomal membrane fraction (LP1), which is enriched in postsynaptic density. All centrifugations were carried out at $4^{\circ} \mathrm{C}$. LP1 pellets were resuspended in TEVP. The $\mathrm{H}$ and LP1 fractions were solubilized with the addition of SDS to $1 \%(\mathrm{v} / \mathrm{v})$ and used for protein concentration measurement and Western Blot Analysis. All fractions were saved and stored at $-80^{\circ} \mathrm{C}$.

\section{Western blot analysis}

Two independent protein analyses were performed. In the first analysis, all saline-treated animals ( $n=10$ per post-SA treatment group) were compared across post-SA conditions (i.e., 8 saline samples from Post-SA treatment conditions (2-3 samples from each Post-SA treatment) were loaded onto each gel and the mean percent changes compared to Home samples on the same gel were determined). This was done to identify any effects of post-SA conditions that were independent of cocaine exposure. The second analysis compared cocaine-treated animals $(n=10)$ to their corresponding saline control group $(n=10)$ for each post-SA treatment (i.e., 3-4 samples each from saline and cocaine treated animals were loaded onto each gel and the mean percent change resulting from cocaine self-administration was determined based on values for saline samples on the same gel). Due to the large number of samples, each of the three comparisons (10 saline and 10 cocaine for each post-SA treatment) was done separately.

Protein concentration was determined by the Lowry based DC protein assay (Bio-Rad, Hercules, CA). Protein samples were resolved by SDS-PAGE according to the method described by Ghasemzadeh et al., 2003. Briefly, proteins were transferred from the gel to a polyvinyldine fluoride (PVDF) membrane using a semi-dry transfer apparatus (Bio-Rad, Hercules, CA). Membranes were blocked for 2 hour at room temperature (Tris-buffered saline containing $3 \%$ non-fat dry milk) and incubated with commercially obtained primary antibody in antibody buffer (blocking buffer containing

[Citation: Journal/Monograph Title, Vol. XX, No. X (yyyy): pg. XX-XX. DOI. This article is @ [Publisher's Name] and permission has been granted for this version to appear in e-Publications@Marquette. [Publisher] does not grant permission for this article to be further copied/distributed or hosted elsewhere without the express permission from [Publisher].] 
NOT THE PUBLISHED VERSION; this is the author's final, peer-reviewed manuscript. The published version may be accessed by following the link in the citation at the bottom of the page.

Tween-20, $50 \mu \mathrm{l} / 100 \mathrm{ml}$ ) overnight at $4{ }^{\circ} \mathrm{C}$, washed with antibody buffer, and incubated with HRP-conjugated secondary antibody for 90 minutes at room temperature. Membranes were washed and immunolabeling was visualized with enhanced chemiluminescence ( $E C L$ method). Chemiluminescent images were captured using a Kodak Image Station 4000MM. Band density was measured using Kodak Molecular Imaging Software v4.0. Commercially available antibodies were used to probe for the presence of proteins. The following primary antibodies were used in this study: mouse NMDAR1 (Millipore, Cat. \# 05-432, 1:3000 dilution), rabbit GluR1 (Millipore, Cat. \# 07660, 1:10,000 dilution), rabbit mGluR5 (Millipore, Cat. \# 06-451, 1:10,000 dilution), mouse PSD95 (Antibodies Inc., Cat. \# 75-028, 1:10,000 dilution), mouse PICK1 (Antibodies Inc., Cat. \# 75-040, 1:3000 dilution), rabbit Homer1b/c (Santa Cruz Biotech, Cat. \# sc-20807, 1:3000 dilution), goat Actin (Santa Cruz Biotech, Cat. \# sc-1615, 1:10,000). The following HRPconjugated secondary antibodies were used: goat anti-rabbit IgG (Millipore, Cat. \# 12-348, 1:20,000 dilution), goat anti-mouse IgG (Millipore, Cat. \# 12$349,1: 20,000$ dilution).

\section{Statistics}

The self-administration data (infusions/session) were evaluated using twoway ANOVA with repeated measures over sessions. Responding on test day (infusions/session) was compared using one-way ANOVA comparing the three post-SA treatment groups. In both cases, differences between groups were determined using post hoc Fisher's PLSD. For analysis of cocaine selfadministration induced alterations in protein levels under each of the three post-SA conditions, immunoreactivity of protein samples from cocaine and saline rats was normalized as percent change relative to the respective mean saline control values for samples on the same gel. Normalized saline and cocaine values were then compared separately for each post-SA condition using Student's t-tests. To permit comparison of cocaine-induced changes across post-SA treatment conditions, saline self-administration effects on protein levels determined from a separate protein analysis were initially compared across post-SA conditions using one-way ANOVA followed by the Fisher's PLSD test to identify any effects of post-SA conditions that were independent of cocaine exposure. For this analysis saline self-administration induced protein alterations under each of the post-SA conditions were normalized as percent change relative to the respective mean Home sample saline values determined from the same gel. In cases where there were no differences following saline exposure across post-SA conditions, percent changes in protein following cocaine self-administration were compared across post-SA conditions using one-way ANOVA, followed by post-hoc testing using the Fisher's PLSD test.

Statistical significance was set at $p<0.05$.

[Citation: Journal/Monograph Title, Vol. XX, No. X (yyyy): pg. XX-XX. DOI. This article is @ [Publisher's Name] and permission has been granted for this version to appear in e-Publications@Marquette. [Publisher] does not grant permission for this article to be further copied/distributed or hosted elsewhere without the express permission from [Publisher].] 